\title{
Oral Carcinoma and Therapeutic Approaches of Nanotechnology: From Fundamental Concepts, Incidence, Molecular Mechanism to Emerging Treatment Techniques
}

\author{
Siddhartha Dan ${ }^{1} \mathbb{D}$, Sushil Kumar Upadhyay ${ }^{2, *}{ }^{\mathbb{D}}$, Mansi Girdhar ${ }^{2} \mathbb{D}^{\mathbb{D}}$, Mahasweta Mandal $^{3}$, Sakshi $^{2}$ \\ 1 Department of Biotechnology, I.K. Gujral Punjab Technical University Jalandhar, Punjab, India \\ 2 Department of Biotechnology, Maharishi Markandeshwar (Deemed to be University), Mullana-Ambala-133207 \\ (Haryana), India \\ 3 Department of Biotechnology, Oriental Institute of Science and Technology (Affiliated to be Vidyasagar University), \\ Midnapore, India \\ * Correspondence: upadhyay.k.sushil@gmail.com;
}

Scopus Author ID: 57197228358

Received: 28.05.2021; Revised: 8.06.2021; Accepted: 12.06.2021; Published: 13.08.2021

\begin{abstract}
Oral carcinoma is the most general, with a large fatality rate and aggressive cancer that can cause metastasis as it attacks other tissues. The prevalence of carcinoma is a multistep method, requiring the collection of many hereditary changes influenced by a patient's hereditary predisposition and environmental effects, including nicotine, alcoholic beverages, chronic infection, and viral contamination. The data were searched using focal keywords, including oral cancer, molecular mechanisms, treatments, and nanotechnology, through various search engines and the Pubmed database. There are two major types of carcinogenesis genetic manipulation, i.e., tumor suppressor genes and oncogenes. Tumor suppression genes can be inactivated throughout genetic phenomena, such as mutations, loss of heterozygosity, deletion, or epigenetic alterations such as methylation of DNA or dynamic modification of chromatin. Oncogenes can be activated through overexpression due to gene amplification, enhanced transcription, or a variation in structure due to mutation, leading to enhanced transforming activity. The current review focused on enhancing cancer therapy techniques using nanomedicines, including nanoscale medicine transfer systems' design, characterization, production, and utilization. Instruments for diagnostic investigations and medical devices are for nanotechnologiesbased therapies are polymeric nanoparticles, nanostructured lipid carriers, gold nanoparticles, and cyclodextrin complexes, which are promising apparatuses for symptomatic tests and helpful treatment gadgets. The present investigation's keen interest was the molecular mechanisms of oral carcinogenesis and the application of biologic therapies to target altered molecules in oral carcinoma and nano-based drug delivery system.
\end{abstract}

Keywords: oral carcinoma; mouth cancer; nano therapy; tumor suppressor gene; oncogenes; nano drugs; carcinogenesis.

(0) 2021 by the authors. This article is an open-access article distributed under the terms and conditions of the Creative Commons Attribution (CC BY) license (https://creativecommons.org/licenses/by/4.0/).

\section{Introduction}

Oral carcinoma is one of the ten most widespread carcinomas worldwide and formed in association with pharyngeal cancer, i.e., the sixth most common cancer worldwide [1]. Worldwide, 378,500 new cases of intraoral cancer are estimated each year. In developed 
countries, oral cancer is the least common, but, overall, it is the eighth most common form of cancer. Though the ranking is a big thing between countries, for example, in northern France regions, oral cancer is the most common among men as well as in few countries like Sri Lanka, India, Pakistan, and Bangladesh [2]. The global incidence rate of the lip, the cavity of the oral and pharyngeal cancers of 529,500 is predicted to increase by $62 \%$ to 856,000 cases by 2035 as compared to $3.8 \%$ of all cancer cases due to changes in demographics [3]. Oral cavity and hypopharynx cancer are extremely usual in the regions of Asian countries [3]. 1/3 ${ }^{\text {rd }}$ of global cases and 1/2 of oral cancer deaths from Southeast Asia have been reported [4]. In some parts of India, oral carcinoma can be represented over $50 \%$ of all cancers and is the most common cancer in the male and the third most usual among the female population due to oral deodorant habits like chewing tobacco, betel nut related are quid chewing, tobacco smoking, smoking, as well as other factors such as alcohol consumption, low socioeconomic status, poor hygiene, poor diet and viral infections, chronic irritation from ill-fitting dentures, rough or fractured teeth $[2,5]$. Buccal mucosa and tongue are the most probable sites of occurrence of oral squamous cell carcinoma (OSCC) [6]. Oral cancer affects men more often than women, although the proportion is getting equal, and in present times the number of cases is increasing in older women and younger women [2, 7, 8]. It copiously affects older persons and the middleaged [2]. However, the incidences of OSCC are increasing among individuals under 45 years of age groups $[9,10]$.

Oral squamous cell carcinoma (OSCC) is a well-known malignancy or malevolence which almost covers more than $90 \%$ of all oral carcinoma [11]. The overall 5-year survival rate at OSCC has not increased significantly over the past 5 years. Disease-free and overall survival rates are 58\% and 56\%, respectively [12]. Establishing an early diagnosis is the most important task in the first stages of the disease [13]. Although there are certain areas in which it is found more, still OSCC can appear in any place in which the most common places are the tongue and floor of the mouth [14-18].

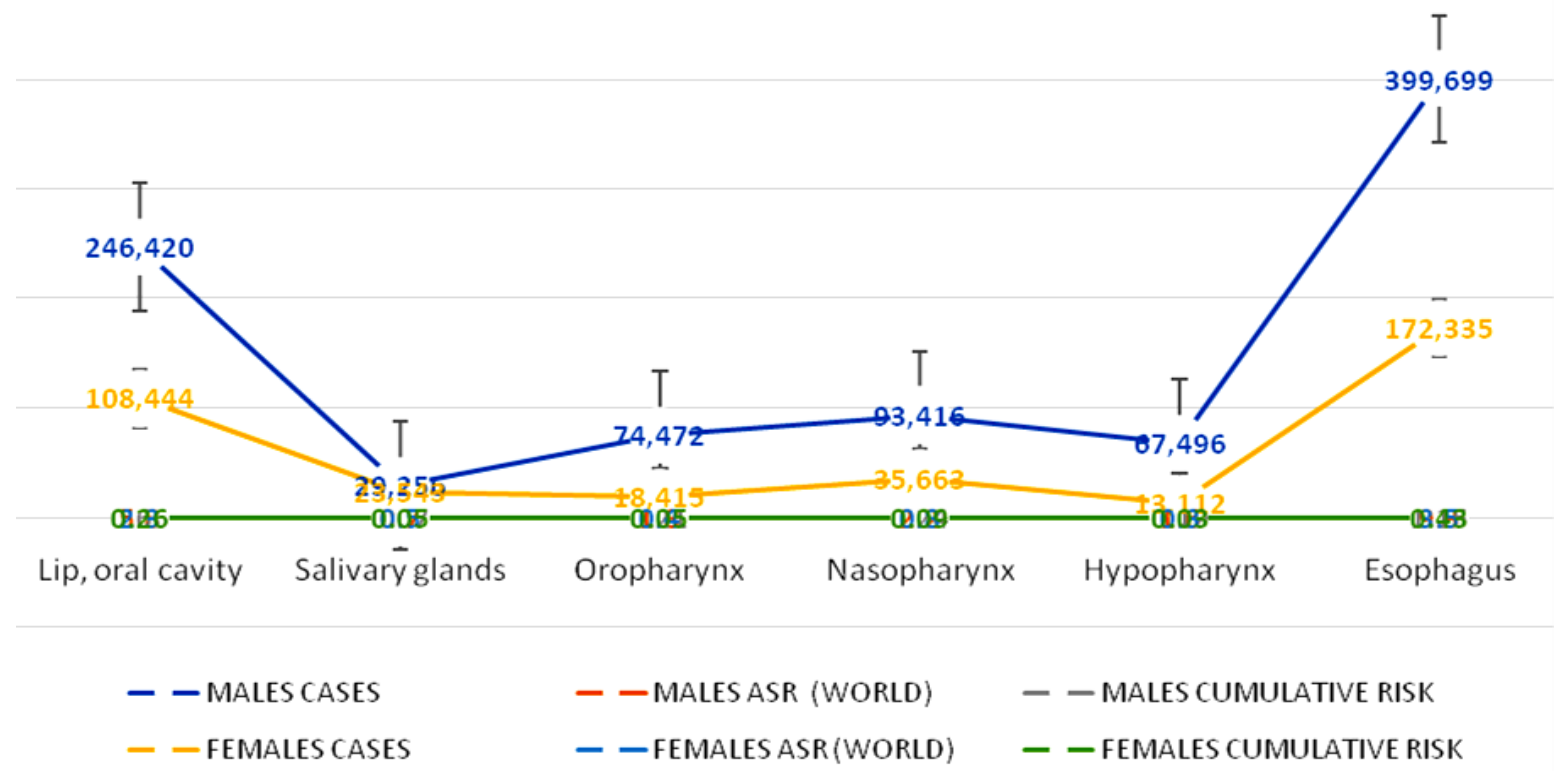

Figure 1. The incidence (cases, age-standardized rate, cumulative risk) for oral cancers combined (including nonmelanoma skin cancer) by sex in 2018. Created based on data available in [26].

Other regions are the involvement include the bouquet mucosa, the retromolar region, the gingiva, the soft palate, and, less frequently, the back of the tongue and the hard palate. Lips are more frequently involved in few geographic regions [19]. The development of https://biointerfaceresearch.com/ 
symptoms of oral cancer is not dependent on the stage of the disease. Large tumors can be asymptomatic and slow-growing [20]. Cancerians of the oral cavity and oropharynx represent about $3 \%$ of all malignancies in men and $2 \%$ of all malignancies in females in the United States. It is estimated that these tumors will cause 28,900 new cases in 2002 and 7,400 deaths in the United States [21-23]. OSCC, which arises from the oral mucosal lining, is responsible for more than 90 percent of these tumors [22, 24, 25]. The annum incidence of oral and pharyngeal cancer in African Americans,i.e., 12.4 cases per 100,000 population, is higher than in whites,i.e., 9.7 per 100,000 cases; the Highest incidence rate is among African-American men (20.5 cases per 100,000 population) [21, 25]. The incidence and mortality (Cases, AgeStandardized Rate, Cumulative Risk) for oral cancers combined (including nonmelanoma skin cancer) by sex in 2018 is well documented (Figures 1, 2) [26].

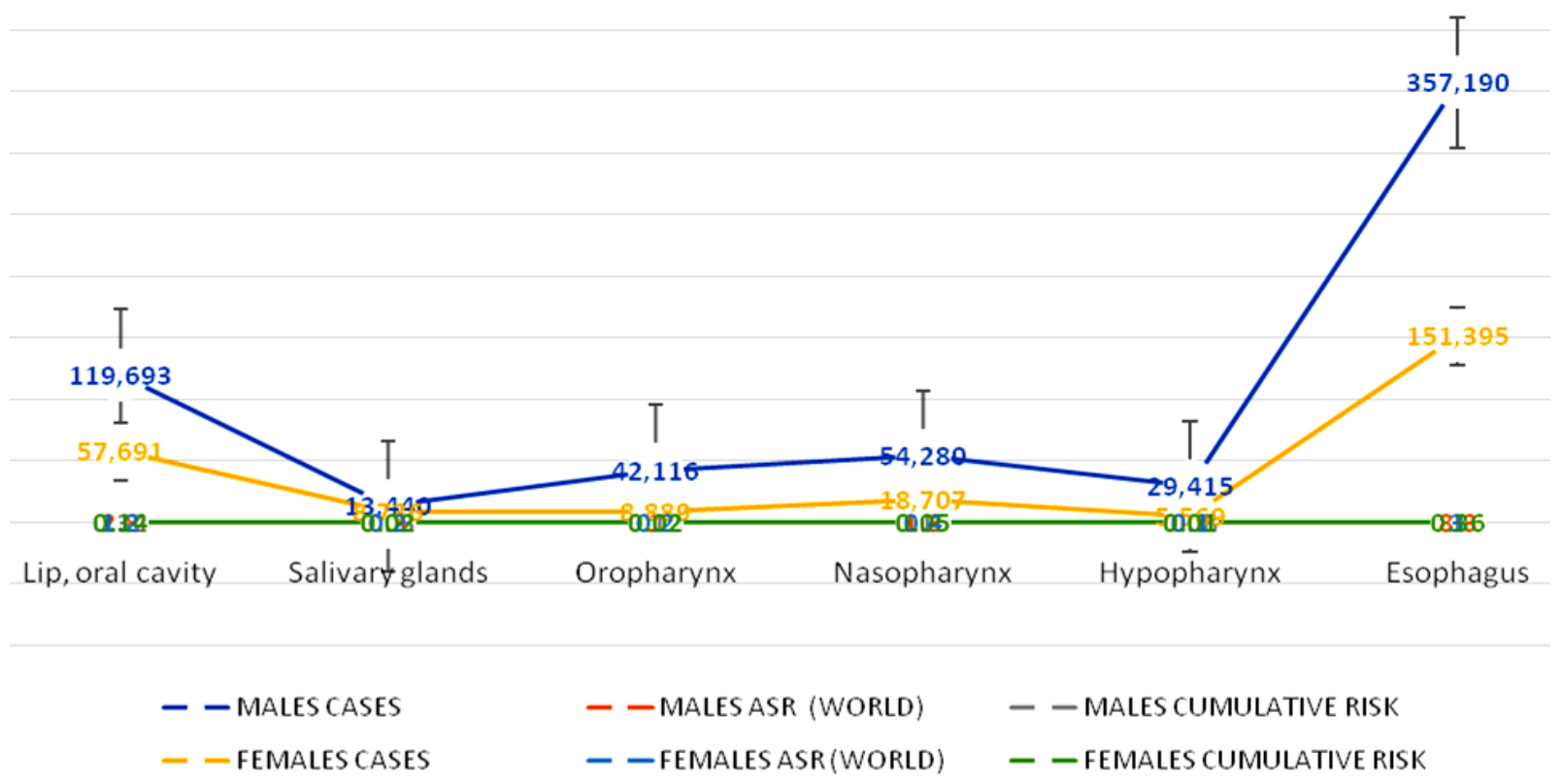

Figure 2. The mortality (Deaths, ASR, Cumulative Risk) for oral cancers combined (including nonmelanoma skin cancer) by sex in 2018. Created based on data available in [26].

\section{Oral carcinoma}

A profoundly perplexing multifocal process is oral cancer. A few hereditary changes influence the squamous epithelium. Utilizing a few biological techniques and strategies to analyze oral precancerous injuries and malignant growth may improve the early location of undetectable adjustment under the magnifying lens. This would distinguish at a high danger of creating oral malignancy [27]. The normal oral malignant growth and grouping of hereditary adjustment history are outlined through a schematic diagram (Figure 3). Understanding Oral cancer, there are several ways to deal with the molecular basis [28-30]. These are including the techniques of microarray, array comparative genomic hybridization, methylation microarrays, mitochondrial arrays and micro-RNA arrays, proteomics (the study of protein), gene expression microarrays [31]. The high-flow capacity view-point is recently being used to find oral malignancy biomarkers in the form of serum and saliva biofluids [31]. 


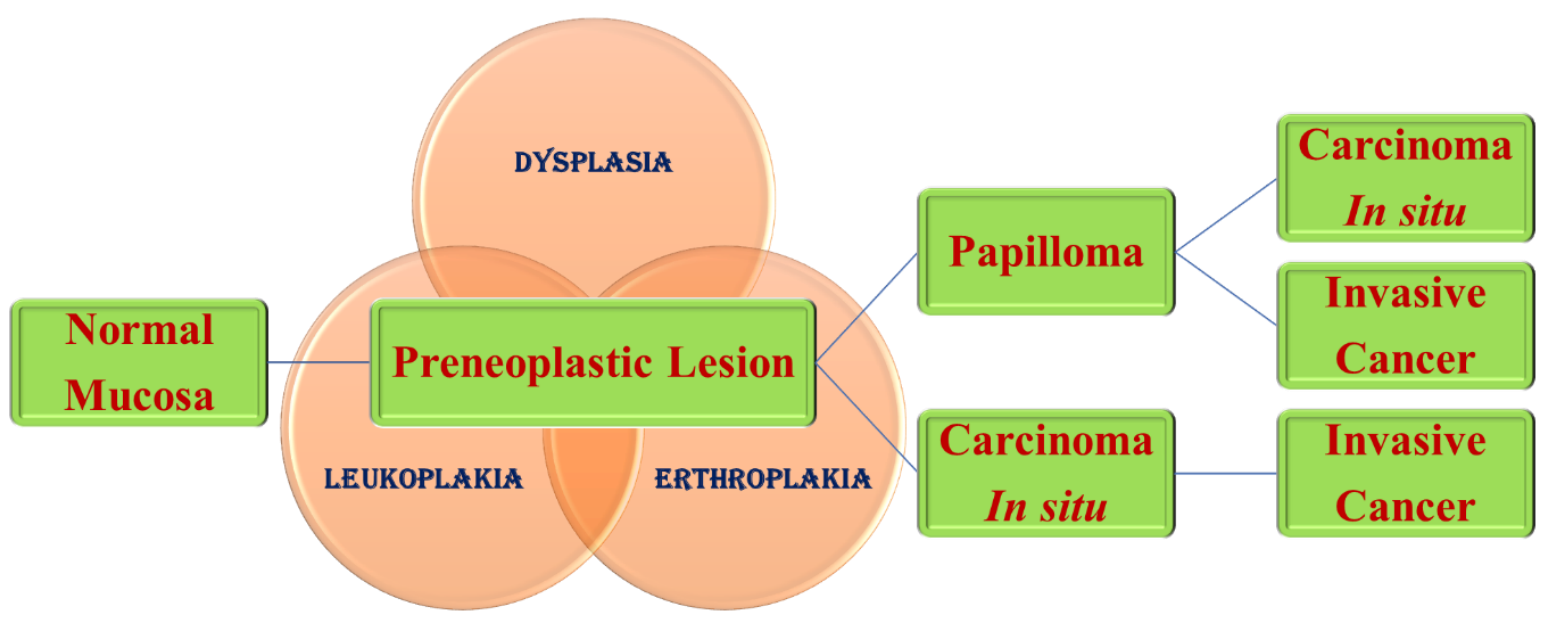

Figure 3.The normal oral malignant growth and grouping of hereditary adjustment history.

Sometimes the potential development of cancer at various multiple-locus referred by Field cancerization $[32,33]$. This has been observed during cancer development in tissues covered with squamous epithelium, i.e., tumors of the head and neck, and transitional epithelium, i.e., multiple layers of epithelial cells and the urinary system organs, known here as urothelium carcinoma. It is clear that the cancer of oral, like carcinomas, develops over many years in another tissue, and during this period, there are various and multiple sites of neoplastic conversion throughout the cavity of oral. The expression of mutations in exons of tumor suppression genes can also be defined as a "Pre-malignant field defect". One such p53 is also a tumor suppressor gene, and mutations of p53 have been observed in different loci or sites of potentially malignant [34]. Decreased tumor suppression activity by genes and the development of the mutation in p53 are associated with an expanded hazard for smoking and mouth cancer rising [35]. That's why multifocal representations and mutational manifestations of the genes of tumor suppressors can be long-term (about $20 \sim 40$ years) consequences for various environmental and exogenous factors. The continued presence of mutations can (may or may not) indicate DNA repair and apoptosis changes, increasing the likelihood of future conversion. Interpersonal adaptations that modify the survival ability to transform cells may also increase the level of resistance to therapeutic control. Current genetic analysis has shown that the carcinoma that develops at distant locations within the oral cavity is often derived from a single initial clone [36]. The multiplicity of the oral cancer steps makes it difficult to inhibit cancer progression through surgical ejectment of a potentially malignant lesion [37].

\subsection{Number and morphology of chromosomes in oral carcinoma.}

Boveri spoke of tumor cell chromosomes, and changes in these chromosomes led to the conversion of malignant proliferation in general [38]. The most common feature of human cancer or tumors, including oral cancer, is Chromosomal instability (CIN). Several reasons for chromosomes are instability, although the elementary factor appears to be defects in chromosomal isolation, telomere stability, cell cycle regulation, and DNA damage repair [39]. The expression of 63 karyotypes has been portrayed in human oral disease in which recurring loss of chromosome numbers 9, 13, 18, and Y deletion are more normal. Repeated deletions of the chromosomal area involved in the arms of 3p, 7q, 8p, 1lq, 13q, and 17p, and in the short arm of all chromosomes in which the centromere is located very close to one end of the chromosome, i.e., acrocentric chromosomes can produce oral cancer $[40,41] .2 / 3^{\text {rd }}$ of all neck 
and head cancer cells have a deleted region located on chromosome 9p21-22 [42]. Oral carcinoma cells can be divided into two types in terms of genotoxicity. Major changes occur mostly in proto-oncogenes and some tumor suppressor genes (TSGs), resulting in a gain of function. Changes in recessives can be caused by transformation, most often in growthinhibitory pathway genes or regularly in TSGs, and cause loss of capacity [43-44].

\subsection{Alteration of regulatory pathways during oral carcinogenesis}

Oral cancer is a multistep process in which genetic events are altered quantitatively or qualitatively within signal transduction pathways that regulate normal cellular physiology [4547]. Under normal circumstances, the strongly controlled excitatory and inhibitory pathways under these controls include direct oral cytology fundamental cell potential. Fundamental cell capacities under these controls incorporate cell division, separation, and senescence. Although cellular pathways within the oral keratinocyte (the cell epidermal that produces keratin) may be diverse, they contain similar fundamental elements. Cell surface receptor binds to a cellular ligand such as a growth factor. Inhibitory or excitatory signals generate by the receptor-ligand complex and sent via intracellular and nuclear messengers that can either directly alter cell function or stimulate the transcription of genes whose protein effects are altered (Figure 4) [48]. Oral carcinoma results from the accumulation of changes in excitatory and inhibitory cellular pathways, which can occur at any stage of any route.

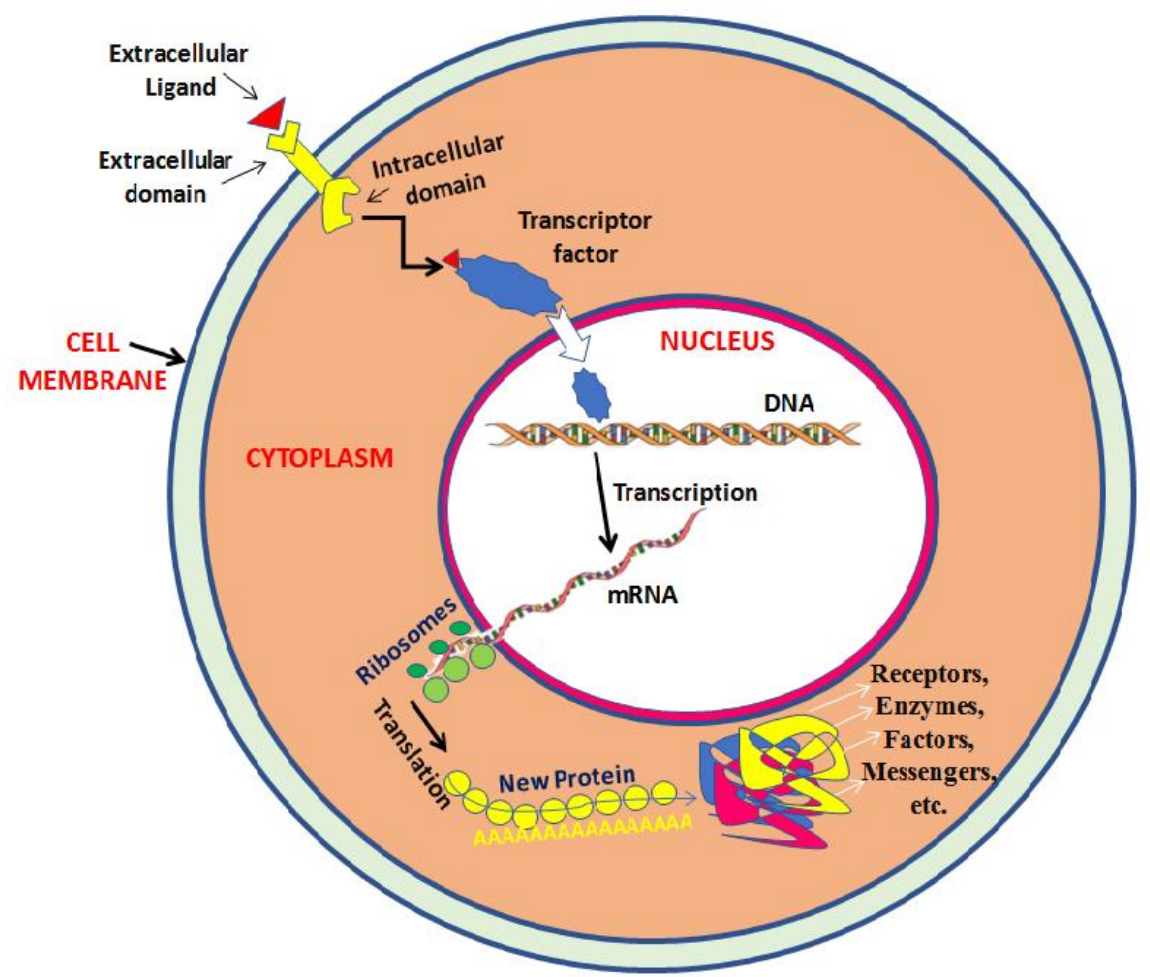

Figure 4. Signal transduction pathways for the synthesis of new proteins.

As the cell gathers these changes or alterations (mutations), it becomes functionally independent of the surrounding oral surface, i.e., epithelium formed by its normal oral keratinocyte's neighbors [49]. Normal cellular functions tightly regulated by excitatory and inhibitory pathways precipitate into the tumor cell, allowing it to divide more rapidly, sequester blood vessels, producing abnormal structural or functional changes. Increases remove or amplifies signals for and invades normal tissue at local or distant places [50]. The histologic 
progression of oral cancer from hyperplasia to dysplasia, followed by severe dysplasia and ultimately invasion and metastasis, is thought to reflect the accumulation of these changes [45,51]. The general cellular circumference is directed through an inducible and suppressible process that permits the cell to explain its reaction to both inside the cell and outward pressure depicted through signal transit routes (Figure 4). Extracellular ligands, for example, development factors, cellular proteins, bond particles, and so forth, tie cell surface receptors. These receptors start biochemical pathways, prompting primary or physiological reactions inside the cell. The second carrier will start modification in gene expression by sequencespecific DNA-binding factor. Gene expression finishes in the creation of proteins coded from DNA in the cell. The DNA is moved into carrier RNA (mRNA), which moved out of the nucleus into the protein in the cytoplasm. The encoded protein might be a development factor, receptor, intracellular courier, record factor, an underlying protein, and so on that is needed to evoke a cell reaction [52].

\section{Oncogenes in oral carcinoma}

A cancer gene (oncogene) is a gene that enables proteins to transform cells and induce cancer. There are two major types of genes, i.e., proto-oncogenes and the second is tumorsuppression genes, that play important roles in cancer progression. These genes encode several proteins that help control cell growth and proliferation, but the mutations in these genes may contribute to cancer development [53]. The conversion or the activation of proto-oncogenes in an oncogene usually involves a gain-to-function mutation. Proto-oncogenes may produce oncogenes at least three mechanisms,i.e., (a) Point changes (mutations) in proto-oncogenes that bring about a constitutively acting protein item, (b) localized reduplication (gene amplification) of a DNA portion that incorporates proto-oncogenes prompting overexpression of the encoded protein, (c) chromosomal movement that brings a growth-regulatory gene heavily influenced by an alternate advertiser and that causes the improper manifestation of the gene. A few cell oncogenes are homologs of retroviral oncogenes (e.g., the ras genes) and have been involved in oral cancer [45,54-55]. Uncommon and unusually manifestations of the proto-oncogene like epidermal growth factor receptor (EGFR), members of the ras family, hst, int-2, c-myc, Parathyroid adenomatosis 1 (PRAD-1), and bcl is accepted to take an interest in oral carcinoma development are in Table 1 [56-59].

Table 1. Few famous cancer genes (oncogenes) and encoded proteins.

\begin{tabular}{l|l|l} 
Oncogenes types & Oncogenes subtypes & Function \\
\hline \multirow{2}{*}{$\begin{array}{l}\text { Nuclear Transcription Regulators } \\
\text { (Nuclear) }\end{array}$} & jun & Transcription factor \\
\cline { 2 - 3 } & fos & Transcription factor \\
\cline { 2 - 3 } & erbA & Member of Steroid Receptor Family \\
\hline \multirow{2}{*}{ Intercellular Signal Transducers } & abl & Protein tyrosine kinase \\
\cline { 2 - 3 } & raf & Protein serine kinase \\
\cline { 2 - 3 } & gsp & G-protein $\alpha$ subunit \\
\cline { 2 - 3 } & ras & $\begin{array}{l}\text { Guanosine triphosphate / Guanosine } \\
\text { diphosphate -binding protein }\end{array}$ \\
\hline Apoptosis Inhibitor (Cytoplasmic) & Bol2 & Upstream inhibitor of caspase cascade \\
\hline Mitogen (Extracellular) & sis & Secreted growth factor \\
\hline Mitogen Receptors (Transmembrane) & erbB & Receptor tyrosine kinase \\
\cline { 2 - 3 } & fms & Receptor tyrosine kinase
\end{tabular}

Oncogenes turn into growth-promoting regulatory genes that promote development or proto-oncogene. It controls the signal transduction path of the cell [60]. Mutation of these proto-oncogenes by point mutation, rearrangement, and amplification leads to either a "gain- 
of-function" change in the hyperactivity of these excitatory proteins [60]. Although oncogenes alone are not sufficient to convert a normal oral keratinocyte into a malignant one, they appear to be important initiators of the process [61]. A single proto-oncogene mutation produces malignant transformation has been made on cells that have undergone multiple "Potentially malignant" genetic transformations [52,60,62]. Exchanged expression of these growth promotors may occur during the signaling transduction pathway in oral keratinocytes [52]. Oncogenes are most commonly associated with solid tumors, which belong to the myc and ras families, and head and neck cancers are analyzed. In addition, erbB-1, implicated in multiple squamous cell carcinomas, has also been studied in oral cancers, as 95\% are histologically identified as squamous cell carcinomas. (SCC) [63-65].

\subsection{Growth factors, receptors and signal-transduction.}

There are seven class of proteins involved in cell growth control: (i) Growth factors, (ii) growth factor receptors, (iii) signal-transduction, (iv) transcription factor, (v) pro-or antiapoptotic proteins, (vi) cell cycle control proteins, and (vii) DNA repair proteins $[52,66]$. The expression of the mutant form of these proteins can result in cancer. For example, the growth factor, a type of extracellular ligand bound to the cell surface receptor and the receptor-ligand complex, generates excitatory or inhibitory signals sent through the intracellular and nuclear messengers that can alter the functioning of the cell by changing the effects of the proteins. During oral carcinogenesis, the growth factors are de-regulated through elevated production and autocrine stimulation (Figure 5) $[55,67,68]$. The primary stages are oncogenesis, TGF- $\alpha$ (Transforming Growth Factor-alfa) is overexpressed prior by the hyperplastic epithelium then through the infectious Intrusion, specifically the eosinophils, the overlying oral epithelium. Be that as it may, the other protein of this gene group Transforming Growth factor-beta is perceived for the tumor silencer just as the induce action [68-71]. PDGF (platelet-derived growth factors) manifested by the tumor cell conclude to the slft signaling process that directs malignancy and tumor development [72].

The cell surface receptor binds to the specific ligand, which activates a cascade of intracellular biochemical steps. The protein phosphorylation regulation is the major event in the cellular function and gene expression. Alteration/mutation in the genes encoding to cellsurface receptors results in the elevated number of receptors or production of a constituent ligand-independent mitogenic signal [73-75]. The cell surface EGFR,i.e.,170,000 Dalton, tyrosine kinase transmembrane receptor along with a member of the human EGFR (HER)ErbB family which constitutes four transmembrane receptors that interact with each other, i.e., EGFR/ErbB1/HER1, ErbB2/HER2/neu, ErbB3/HER3, and ErbB4/HER4 [76]. The interaction between the ligand and its specific receptor can result in either heterodimerization or homodimerization of receptor and ligand complex; then intracellular tyrosine kinase portion is phosphorylated and leading to downstream activation of complex interacting signaling pathways, which include the Ras/Raf/MEK/ERK and the Ras/PI13K/PTEN/AKT/mTOR pathways. The biological ligands (EGF, TGF- $\alpha$ ) and EGFR are overexpressed in human oral cancers [77-80].

In recent research, the largest family of cell-surface molecules, G-protein-coupled receptors (GPCRs), involved in signal transmission, plays an essential role in tumor growth and metastasis [81]. 


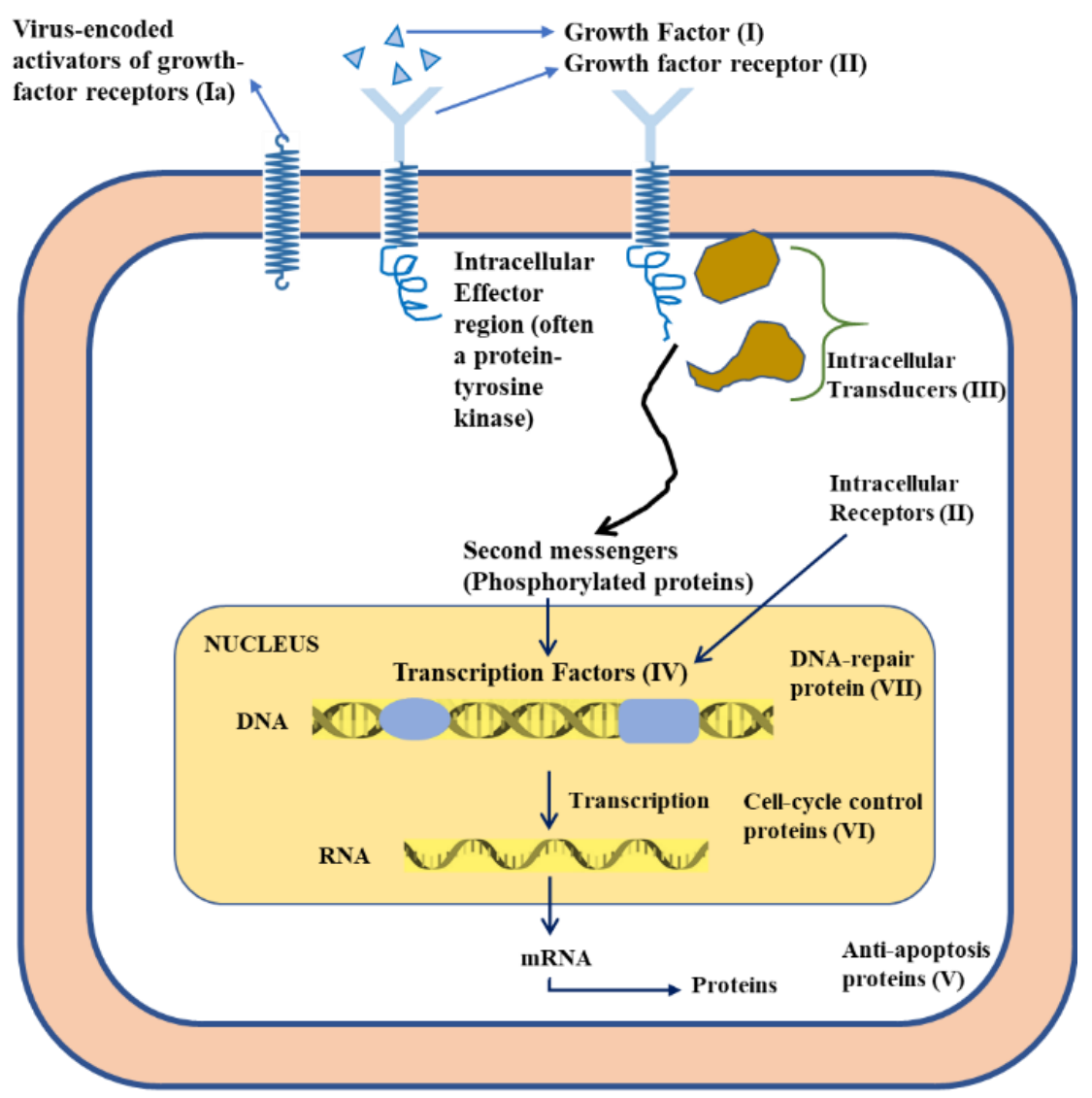

Figure 5. Signal transduction pathway of growth factor is de-regulated through elevated production and autocrine stimulation.

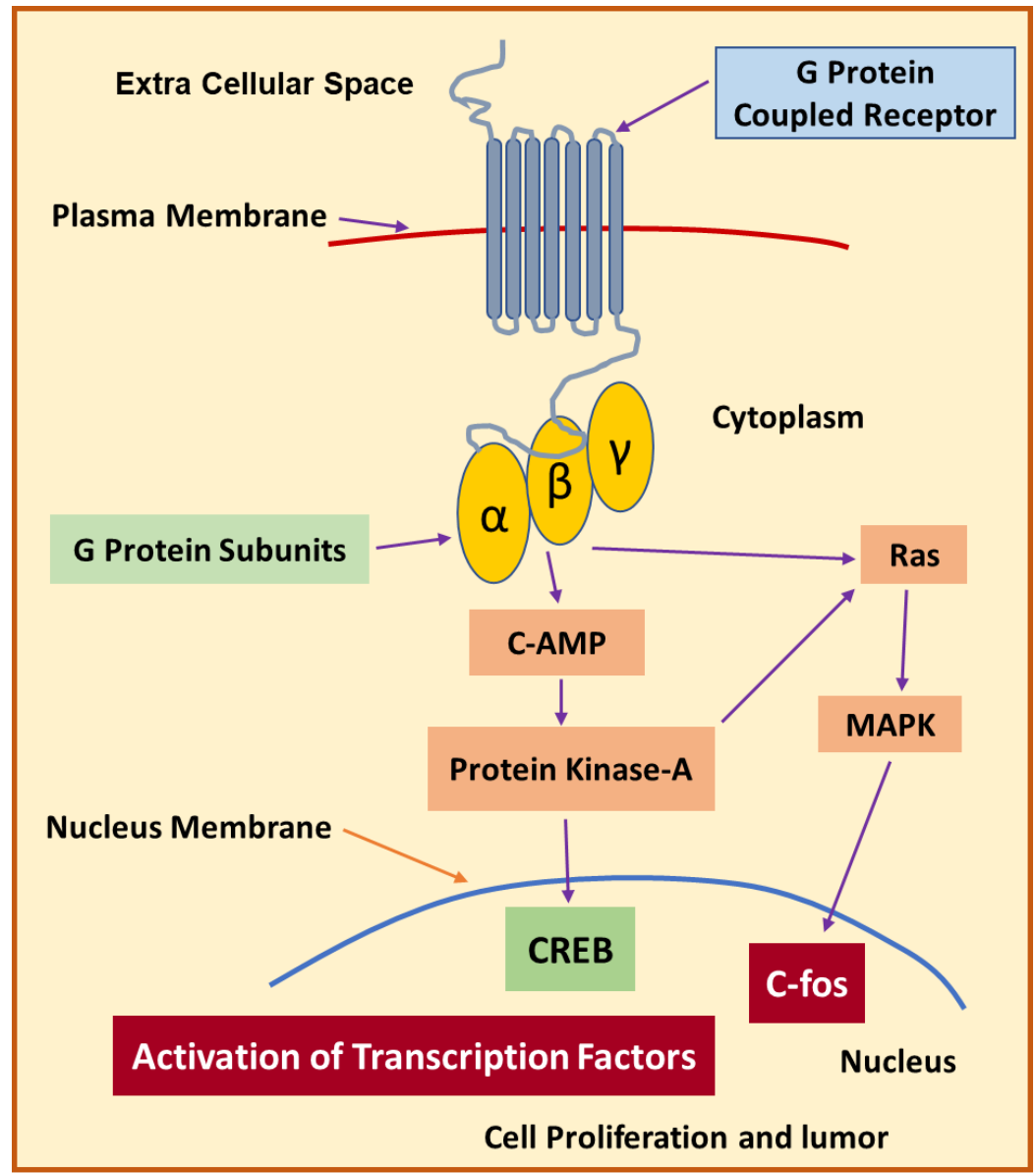

Figure 6. A diagrammatic representation of signal transduction mechanism of G-protein-coupled receptor. 
The specific members of the GPCRs family are involved in the transmission of signals from the extracellular environment to the cytoplasm. The chemical or physical stimuli can lead to the activation and promotion of the interaction between the GPCRs and the G-protein on the intracellular side of the membrane. GPCRs constitute the largest integral membrane protein family in the human genome with over 1000 members and are grouped into 5 classes [82, 83]. Adrenergic receptors (ARs) are kept in the amine group of class A receptors and involves two main subfamilies, $\alpha$, and $\beta$, which differ in tissue localization and ligand specificity as well as in G-protein coupling and downstream effectors mechanisms. Each sub-family is further subgrouped in- $\alpha 1, \alpha 2$, and $\beta 1, \beta 2$ - adrenergic receptor [84, 85]. Recent research has studied the expression of $\beta 2$-AR in breast, colon, and prostatic cancer. An invitro experiment (by Wan et al.) on mutant S49 mouse lymphoma cells proved to activation sequence of a GPCR by its specific ligands and downstream effectors molecules, as $\beta$-adrenergic receptor/Gs $\alpha /$ adenylyl cyclase/cAMP/PKA/Rap1/B-Raf/MEK/MAPK (Figure 6) [86-90].

\subsection{Transcription factor.}

Intracellular signaling molecules are commonly called second messengers that are released by the cell. Second, messengers relay to signals received at the receptors on the cell surface, such as the arrival of protein hormones, growth factors, etc., for targeting the molecules in the cytosol and/or nucleus and triggering the physiological changes such as proliferation, differentiation, migration, survival, and apoptosis. In response to the exposure to the extracellular signals first messengers (extracellular substance), the cell releases second messenger molecules [91-92]. The second messengers can be activated intrinsically, delivering a continuous rather than a ligand-regulated signal [74]. Out of all the members of the intracellular signaling pathway, only the members of the ras gene family (H-ras, K-ras, N-ras) have been examined in the human oral cancer, and all of them encodes for the related protein p-21 that has been localized to the cytoplasmic side of the cellular membrane which transmits mitogenic signals by binding guanosine triphosphate (GTP). The mitogenic signal's termination occurs by converting GTP to guanosine diphosphate by hydrolysis, but after the mutation of the oncogenes ras, this transformation can be prevented, resulting in continuous stimulation [52].

In activating another gene, some proteins participate and have a crucial role, referred to as transcription factors, and their regulation and activity may alter in oral cancer. The regulation of the functioning of many of these proteins is made by the receptor-activated second messenger pathways, and the neutralization of these genes could result in the blockage of the cell cycle, thereby preventing mitogenic and differentiation responses to growth factors. The C-myc gene helps regulate cell proliferation and frequently overexpresses in oral cancer resulting in the amplification of the gene [93, 94]. The transcriptional factor c-myc induces apoptosis by activating c-myc and another gene Rb-1 (a TSG). The nuclear protein pR6 interacts with the c-myc gene, prevents the transcription, and helps in inhibiting the cell proliferation c-myc, p53 and pR6 expressed in all carcinomas, irrespective of the differentiation $[95,96]$. Transcriptional factor PRAD-1, also known as cyclin D1 or CCND1 is encoded by the PRAD-1 gene, which controls the G1 to $S$ transition of the cell cycle and the Rb gene product also acts as cell cycle promoter. The PRAD-1 gene is amplified in 30-50\% of cancers in the neck and head [97]. 


\subsection{Pro-or anti-apoptotic proteins.}

The discovery of the BCL-2 gene led to the introduction of a new class of genes that helps regulate cell growth through the inhibition of apoptosis. It has been found recently that BCL-2 functions as a cell death repressor, and with its discovery, it has been expanded that it forms heterodimers with the protein product of the bax gene. The overexpression of the bax counteracts the activity of the death repressor of BCL-2 and also it has been suggested that the ratio of BCL-2 to baxdepicts the death or survival of cells during the stimulation of apoptosis [98]. In carcinogenesis, the importance of this family of genes is not certain, but the promotion of the protein product of BCL-2 helps in the cell's survival by the inhibition of apoptosis thus, conferring an advantage of growth or survival to the neoplastic cells [99]. The overexpression of the BCL-2 gene has been reported in a number of tumors, including those arising in the breast [100], lung [101], thyroid [102], and skin [103,104]. This study expands the range of tumors expressing BCL-2 by demonstrating the protein expression in squamous cell carcinomas at other sites consisting of those arising in the skin and lungs [103,105].

The histological features and the aetiological factors of non-small cell lung and oral carcinomas are similar, and the expression of BCL-2 by both tumors is not unexpected. However, the identification of the moderate or strong BCL-2 protein expression was $60 \%$ of the tumors in this series compared to studies compared to the studies of non-small cell carcinoma where the prevalence of immunoreactivity was less $[105,106]$. The differences in the quantification of the positive cells may only account partially for the differences in the expression level and genuinely may reflect the biological difference between the tumors at the variable sites. The overexpression of the BCL-2 was most common in the poorly differentiated group of the squamous cell carcinomas, where 6/7 (86\%) tumors have depicted the strong staining in contrast to only $311(27 \%)$ in the well-differentiated group. In contrast, bux immunoreactivity was more common in the well-differentiated carcinomas with 8111 (72\%) determining strong staining, as compared to the only 217 (28\%) of ht poorly differentiated tumors and are consistent with certain tumors at other sites, such as neuroblastoma, where BCL-2 expression is linked to the poorer tumor differentiation [107].

However, the lack of correlation between BCL-2 expression and the tumor size or clinical stage in this study may reflect the small study population, thereby suggesting the larger cohort analysis required to determine if the overexpression has prognostic significance [108]. BCL-2 has an inverse expression pattern, and bax in the normal epithelium is constant factually that BCL-2 lacks in the terminally differentiated cells capable of apoptosis, such as suprabasal keratinocytes [109]. The expression of the BCL-2 and bax recapitulated in the welldifferentiated carcinomas in the normal epithelium. The expression of Bcl-2 was the strongest in the peripheral cells of the epithelial islands and reduced with the production of keratin. The elevated expression of BCL-2 in the poorly differentiated group may show the lost ability of malignant keratinocytes for terminal differentiation. It also suggests that the cells overexpressing bcl-2 include stem cell phenotype, which is further supported by the lowered expression of bax in poorly differentiated tumors. The ratio of the bcl-2 and bax may contribute to the population's phenotype of cell type in the epithelial carcinomas. Therefore, a predominance of bcl-2 favors a terminal differentiation pathway for the neoplastic keratinocytes and also has an antiapoptotic effect on the cells [108].

In antecedent mucosal epithelial dysplasia, oral carcinoma is thought to be developed, and similarly epithelial dysplasia at the other sites, three well-defined groups are recognized. 
Each of them has a varying risk of transforming to carcinoma [110]. The evolution of the epithelial dysplasia to the carcinoma associated with the genetic events is not well characterized, but in the precancerous lesions, the alterations of the tumor-suppressor genes and the oncogenes have been reported [111-113]. The upregulated BCL-2 protein in the dysplasia adjacent to the invasive carcinoma concludes that this change is an early event in the epithelial carcinogenesis which is constant with the reports of the upregulation of BCL-2 is early in the dysplastic lesions at the other sites [114, 115]. An alternative mechanism that involves the genes that help regulate apoptosis may be essential in epithelial carcinogenesis. The elevated expression of BCL-2 or downregulation of bax would prolong the cell survival and the growth advantage to the dysplastic epithelial cells. Then the existence of the potential for the emergence of a neoplastic clone of cells that is susceptible to a further mutagenic event that would involve a tumor-suppressor or an oncogene will occur. Studies have been conducted to examine the expression of BCL-2 and bax in a large series of dysplastic epithelial lesions [108]. Therefore, it can be concluded that this pilot study depicts an altered expression of BCL2 and bax proteins in oral squamous cell carcinomas. The BCL-2 protein was most frequently overexpressed in the poorly differentiated carcinomas and bax in the well-differentiated tumors. Also, the identification of strong BCL-2 overexpression in dysplastic lesions adjacent to the invasive tumors raises the possibility that BCL-2 dysregulation is an essential early event in the carcinogenesis of the mucosal epithelium [108].

\subsection{Cell cycle control proteins.}

A process in which the excess cells are eliminated and a mechanism for protecting the organism from the cells with DNA mutations also a programmed cell death is referred to as apoptosis. The failure of the apoptosis would result in tumorigeneses as the apoptotic pathway is lost with the damaged DNA, which permits the damage to be perpetuated in the daughter cells and may be accountable for the elevating tumor bulk in the absence of uncontrolled or increased proliferation. The cell cycle has an essential role in this process, and there are two possible stages by which the apoptosis is reached by the cells in which the apoptosis follows abortive cell division such as that caused by DNA damage primarily, and secondly, it may follow and appropriate cell cycle proteins activation [116].

\subsection{Cyclins.}

Evans et al.[117] first identified the regulatory subunits in 1983 as $50-60 \mathrm{kDa}$ proteins named 'cyclins' that were found variable in the concentration throughout the cell cycle. It is known that there are at least eight different human cyclins A, B, C, D, E, F, G, and H that are highly conserved between species [118]. Cyclins A and B were isolated originally from embryos of clam and usually described as mitotic cyclins (although cyclin A has some activity in the $\mathrm{S}$ phase), cyclins $\mathrm{C}, \mathrm{D}$, and $\mathrm{E}$ were cloned from cDNA libraries in humans and were known as rescue cyclin (cln)-deficient yeast [118]. Cyclins D and E are G1 cyclins, and cyclin $\mathrm{H}$ forms a part of cyclin-dependent kinase activating kinase (CAK), and the functions of other cyclins are not fully determined. Cyclin box contains the highly conserved homology of all the cyclins, which acts as a cdk binding site [119-121]. Similarly, a destruction box is found in the N-terminal part of the cyclin molecules A and B [122] and the carboxyl part of cyclin C, D, and E molecules. 
During the S phase, cyclin A is synthesized, and the activation of cyclin A promoter initiates with the onset of the $\mathrm{S}$ phase, and cyclin A's appearance coincides with DNA synthesis [123]. For the $S$ phase, cyclin $A$ is required for the passage from $G 2$ into mitosis [124]. During G1, microinjection of antibodies to cyclin A blocks the $S$ phase, and the completion of this stage is prevented completely by the injection during the $S$ phase [125]. Before cyclin B, cyclin $\mathrm{A}$ is broken in anaphase, and cyclin B includes at least three subtypes (cyclin B1-3) which accumulate during the G2 phase and acts as mitosis. Cyclin B mRNA peaks at the G2/M transition and elevating through the $S$ phase [126-128]. In the late $S$ phase, cyclin B protein appears in the cytoplasm and is broken down in anaphase after cyclin A via a ubiquitindependent pathway [129].

Being $72 \%$ identical between Drosophila and humans, cyclin C is highly conserved between the species [130]. Cyclin C peaks in mid-Gl, suggesting a Gl role, but its precise function is unknown [117]. Cyclin D is an extremely unstable protein and has three sub-types (cyclin D1-3) and is a nuclear protein and its mRNA appears in the cells stimulated with mitogenic growth factors [131] unaffected by transforming growth factor $\beta$ (TGF- $\beta$ ) [131133]. Phorbol ester TPA, an activator of protein kinase $C$, induces cyclin D1 synthesis in stimulated cells invitro, suggesting a regulatory pathway for this cyclin [131]. In early G1, cyclin D2 appears, in mid-G1 cyclin D1 appears, and in late G1 cyclin D3 appears [133-136]. The half-life of cyclin D is approximately 38 minutes [131]. Cyclin D does not have the domain at the amino end of the molecule required for proteolysis [122]. Cyclin D1 disappears from the nucleus, and it becomes cytoplasmic at the end of the S phase [137] but does not show the fluctuations. The level of cyclin D1 also remains constant with minor variations over the length of the cell cycle [131]. The forced expression of cyclin D stopped the differentiation of the cells [138]. There is a sudden initiation of transcription at mid-to-late G1 by cyclin E. TGF $\beta$ reduced the expression of cyclin $E$ in some cell types if acting on the cell prior to cyclin $E$ gene activation [131,133]. Cyclin $\mathrm{E}$ has been shown to have a very short half-life, but the molecular details it is not known [131,139]. Cyclin $\mathrm{G}$ has been identifying the potential transcriptional target of the p53, and It doesn't have a destruction box, and no function has been proved for it [140]. Cyclin $\mathrm{H}$ is found in $\mathrm{G} 2$ and is a part of CAK, which functions by phosphorylating and activating the maturation promoting factor (MPF-the complex formed by cyclin B and p34cdc2) [141].

\subsection{Cyclin-dependent kinases.}

The cyclin-dependent kinases (CDK) have a series of molecules from the 11 genes of the family of cdc 2 gene [142], which reflects the complexity of the eukaryotic cell and the greater number of regulatory functions required. In prokaryotic cells, the number of cdk seems to be sufficient. P34cdc2/CDC28 was discovered as the first cdk in yeast and is seen as homologous to $34-\mathrm{kDa}$ p34cdc2 in humans [143,144]. 33-kDa p33cdk2 was the second cdk to be discovered and the sequence of both the kinases is PSTAIRE on the conserved part of the molecule. Most of the other cdks were not originally checked for cyclin binding and were first reported by Meyerson and colleagues [118,145] and were therefore given names derived from the amino acid sequence from the conserved part of the molecule. The other cyclin-dependent kinases are cdk3 (PSTAIRE), p33cdk4 (PSK-J3) (mol. wt. $33 \mathrm{kDa}$ ), cdk5 (PSSALRE), p38cdk6 (PLSTIRE) (molecular weight $38 \mathrm{kDa}$ ), and cdk7. P33cdk4 and p38cdk6 possess 70\% homology [146]. A 53-kDa protein has been defined by Tassinet al. [147] and has been 
designated cdk8. cdks differ in their specificity for cdks: cyclin A binds to cdk2 and cdc2 [148], while cyclin B specifically binds to cdc2 [149-154]; cyclin D binds to either cdk4 or a cdk6 [117,155], and cyclin E binds with cdk2 [139,156] as well as cyclin $H$ binds with cdk7 [157] and with MAT1 forms CAK [158], and associate with cyclins D1 and D2, cdk5 [159, 160]; cyclin $\mathrm{C}$ is believed to bind cdk8 [147]; The binding cyclin partner for cdk3 is unknown and named cyclin X. Each of these premises has specific goals and actions, and some of them are yet to be identified.

The levels of cdc2are generally constant in the cells that are proliferating rapidly, but at G1/S transition [154,161], a burst of transcription is observed. At mitosis, the activity of cdc 2 rises to a peak, while the activity of cdk 2 rises in the late $\mathrm{G} 1$ or early $S$ phase [162]. The levels of cdc 2 in the non-dividing cells are low, and the molecule's half-life is approximately 18 hours $[118,154]$. A combination of phosphorylation and dephosphorylation and the complex formation are required to activate the cyclin-dependent kinases. CAK phosphorylates cdc2 [118], cdk2 [163], cdk3 [164] and cdk4 [118]. Highly purified CAK can phosphorylate cdc2 and cdk2 without cyclin being complexed with them. However, they only exhibit modest activity when they are phosphorylated in the absence of the cyclin. The conformational change is seen when the cdks are bound to the cyclins, allowing the phosphorylation site to be better exposed [164].

\subsection{Transcription factors ( $E 2 F$ family).}

E2F is known as the global term for a DNA-binding complex that consists of one of the five E2F components, E2F-1 to E2F-5, each of which may form a complex with either DRTF1 protein 1 (DP1) or DRTF-1 protein 2 (DP2). Concerning homology in the binding sites, DP binding sites, and pocket protein regions, all forms of E2F have a similar structure. E2F-1 to 3 preferentially bind with pRb, and E2F-4 and 5 bind pRb related proteins p107 and p130 via their spacer regions $[165,166]$. The binding complex of E2F is involved in the transcription of many genes, e.g., cmyc [118], n-myc, cdc2, cyclin A [124], c-myb, and the EGF receptor gene [118]. All forms of E2F complex recognize the binding region of E2F, and each of them acts on the different genes or in a slightly different way. E2F-1 knockout mouse has been recently produced, which showed hyperplasia and tumor formation after a period of normal growth rather than the expected tissue atrophy [167-168].

\subsection{DNA repair proteins.}

The activation of composite DDR (DNA damage response) pathways consisting of cell cycle arrest, transcriptional and posttranslational activation of the genes involved in DNA repair, inducing DNA lesions and programmed cell death. There are three possible states in case of a great amount of DNA damage that is accumulated within a cell or the incapability to repair all the lesions: senescence, apoptosis, or unregulated cell division leading to tumor formation. The efficiency of the DDR pathways' activation is determined by the nuclear levels of the DNA repair proteins $[169,170]$. Genomic instability results in the incapability of the appropriate response to the DNA lesions and/or DNA repair. Recent research depicts that head and neck carcinogenesis is associated with abnormalities in DNA repair, apoptosis, carcinogen metabolism, and cell cycle control [171]. If the DNA lesions apply to the essential information in the genome, the cells cannot function properly. A variety of repair strategies have evolved to restore the lost information depending on the type of damage on the double-helical structure 
of the DNA. There are two main pathways of DNA repair: single-stranded damage and doublestrand breaks [169].

Single strand damage is a valid system and requires the presence of an intact DNA strand as a template. The single-strand damage repair occurred by three major mechanisms such as base excision repair (BER), nucleotide excision repair (NER), and mismatch repair (MMR). When the DNA lesion is localized within the single nitrogenous base then, the BER is activated. BER pathway evolved to cope with the high level of spontaneous decay products formed in DNA and those damages created upon reactions with natural endogenous substances such as reactive oxygen species (ROS) [172]. This mechanism consists of the following steps, i.e., detection and removal of the damaged base by DNA glycosidase, resulting in the creation of an apurinic or apyrimidinic site (AP site), then cutting the damaged DNA backbone at the AP site by AP endonuclease and removal of the damaged region by lyase or phosphodiesterase then the synthesis of the new strand by DNA polymerase using the complementary strand as a template and last the re-enactment of phosphodiester bond by DNA ligase [173]. Compared to BER, NER leads to removing a larger DNA fragment, and this system repairs DNA lesions consisting of helix-distorting damage, such as pyrimidine dimerization caused by UV light. The proteins XPA (DNA damage recognition and repair factor) and XPC (XPC complex subunit, DNA damage recognition, and repair factor) get incorporated into the damaged region in the first phase. The endonucleases like ERCC4 (ERCC excision repair 4, and TFIIH core complex helicase subunit), ERCC5 (ERCC excision repair 5, and TFIIH core complex helicase subunit), and ERCC3 (ERCC excision repair 3, and TFIIH core complex helicase subunit) finally filled the gap using DNA polymerase and followed by the recreation of phosphodiester bond by DNA ligase as in the BER mechanism [174].

The function of the MMR system is to recognize and repair the incorrect insertion, deletion, and incorporation of nitrogenous bases that occur throughout the DNA replication process, and the activation of this mechanism is dependent on the valid functioning of an enzymatic complex which includes: MutS protein, which forms a dimer and recognizes an incorrect complementary between nucleotides and binds to the damaged DNA: MuH, which attaches at hemimethylated sites along with the impaired fragment, and MutL protein, which activates the MutH peptide and also functions as a mediator between MutS2 and MutH. In the end, the synthesis of a new DNA fragment is catalyzed by DNA polymerase and ligase as the final step. MutS-homolog 2 (MSH2) gene is the crucial part of this system and encodes a protein that recognizes the mismatched DNA by forming two functional heterodimers: MSH2MSH6 and MSH2-MSH3. The first one recognizes the single-base mismatches and short insertion-deletion loops, whereas the MSH2-MSH3 complex is able to detect the larger loops in DNA molecules [175-177]. DSBs are the most fatal and adverse types of damage because of the irreversibility of the changes. The repair of these impairments can be categorized into three major steps: detection, signaling, and correction. Depending on the stage of the cell cycle, an adequate system is activated. In the G1 phase, the non-homologic end joining (NHEJ) mechanism is enabled, whereas homologic repair (HR) is activated in the G2/M phase [169]. Broken ends are bound by Ku70/80 heterodimer during the NHEJ pathway resulting in the activation of DNA-PKcs. The XRCC4 (X-ray repair cross-complementing 4)/ ligase IV complex completes the final step of ligation [178]. The NHEJ system did not require a DNA template and was operative to all the steps of the cell cycle $[179,180]$. 
Resecting of the impaired DNA endings by MRE11 or Exo1 (exonuclease 1) taken place during HR mechanism resulting in the formation of a 3' overhang stabilized by RPA (replication protein A). It was then loaded on the homologous DSB region by the strand exchange protein RAD51 (RAD51 recombinase) and BRCA2 (breast cancer 2, DNA repair associated), resulting in the Holiday junctions intermediate. The HR system seems less practical than the NHEJ in mammalian cells, but the HR mechanism defects enhance cellular radiosensitivity. In response to the ionic radiation exposure, most cells arrest the cell cycle at the G2 phase. The HR mechanism mainly works in the Late-S and G2 phase, and inhibiting this would be a good strategy for the new cancer treatment [181]. During or after the DNA replication, these processes may function and can recognize abnormalities in the DNA structure and recreate the valid structure of a molecule. A large number of mutations can result in an uncontrolled cell division contributing to the development of cancer, apoptosis thereby, elevating the rate of cell aging or the formation of hereditary disorders [169].

\subsection{Tumour suppressor genes.}

Oncogenes alone are not bounded to incite cancer of oral. The inactivation of negative cellular regulators that alter the premalignant cell to a malignant cell is called TSGs. TSGs are considered to be the development of malignancy and are most commonly inactivated by point mutations, deletions, and rearrangements in a copy of the genes [182]. Approximately $70 \%$ of the solid adult tumor, TSG p53, is known to be mutated. The protein p53 acts as a barrier for the cell division at the G1 to S boundary, encourages DNA repair after DNA damage, and entices apoptosis. These functional objectives are carried out by the ability of p53 protein to regulate the expression of various genes like the WAF1/CIP gene, which encodes $\mathrm{p} 21$ protein. p21 is served as an inhibitor of cyclin and cyclin-dependent kinase complexes [183-185]. Smoking and tobacco use are affiliated with the mutation of the p53 gene in head and neck cancer [186]. The other gene TSGs, doc-1, is mutated in malignant oral keratinocytes, leading to a diminution of gene expression and functional protein [187].

\subsection{Function of p53 as a tumor suppressor gene.}

The p53, the tumor suppressor gene, is a gene with a major role in apoptosis. The protein it codes belongs to a family with three members: $\mathrm{p} 53$, p63, and p73. All of them have a DNA-binding identity of about $60-70 \%$ region of the amino-acid, and all three can induce apoptosis [188]. The different stimuli like DNA damage, ionizing radiation, UV irradiation, hypoxia, heat shock, oncogene activation, and cytotoxic drugs activate p53 [189]. The p53 commences responses involving cell cycle arrest, apoptosis, DNA repair, and differentiation through transcriptional activation of specific target genes that carry p53 DNA binding sites. The p53 induces the expression of some Bcl-2 family genes, including those of Bax and multiple BH3-only proteins, e.g., Bid, Noxa, and PUMA [190]. Also, p53 can ligate to one or more anti-apoptotic mitochondrial proteins, e.g., Bcl-XL, consequently restraining the Bax/ Bak mitochondrial pore configuration and, as a result, cytochrome $\mathrm{c}$ release [191, 192]. Finally, p53 can also build apoptosis activity through transcriptional repression of certain genes that lack consensus binding site motifs [193, 194]. 


\subsection{Mechanistic views of how mutant p53 exerts its function.}

It is well established that inactivation of p53 and interpretation of mutant p53 can support cells with additional growth and survival assets, such as embossed proliferation, prevarication of apoptosis, and chemoresistance [195]. In accession to the further survey, the structures underlie the aspect of mutant p53 at the different steps of tumor progression. It was imperative to enact animal models that indicate mutant p53 in a restrained manner. Indeed, the current data gathered over the usage of such in vivo models upholding the notion of GOF properties seized by mutant p53, urging the cells headed for the movement, invasion, and metastasis. Prior work acquiesces that although p53 knockout mice evolve neoplasm at an immense frequency [196], they exhibit low metastasis or invasive growth [197]. In distinction to this, mice knocked with p53 $\mathrm{R} 270 \mathrm{H}$ or $\mathrm{R} 172 \mathrm{H}$, corresponding to the human hotspot mutants p53R273H and p53R175H, respectively, established the highly esteemed metastatic tumors $[198,199]$.

Additionally, the mutant p53 can augment and reinforce cell migration and invasion in vitro assays [200, 201]. Importantly, the data imply that the selection for oncogenic Ras and mutant p53 occurs in early neoplasms to enhance growth and survival. They play an equally important role at the late stages of tumor progression in granting TGF $\beta$-induced metastasis [201]. Initiation of metastasis has plenty of phenotypic similarities with epithelial-tomesenchymal transition (EMT), incorporating loss of cell-cell adhesion and an increase in cell motility. Although WT p53 was shown to forbid EMT [202, 203], mutant p53 was found to promote EMT by facilitating the functional objective of the key transcriptional regulators of this process, TWIST1 and SLUG [202, 204, 205], an additional mechanism through which mutant p53 was shown to boost cell invasion via the inhibition of TAp63, thus promoting TGF $\beta$-induced metastasis and boosting integrin recycling pathways that enhance invasiveness [200-201]. The other possible GOF effect of mutant p53 on tumor progression may be attained through the positive regulation of angiogenesis, as tumors that bring about following mutant p53 knockdown contribute less vascularization [206]. Taken together, it seems that in certain cancers, p53 is mutated in the late tumourigenesis processor plays a powerful act in those advanced stages, leading to a more aggressive and invasive tumor [195].

During the precedent span, establishing an in vitro figurine in which numerous steps in tumor progression can be dissected and associated with specified molecular events [207]. Using the genomic technique approach, we analyzed distinct transcriptional signatures that can compensate with p53 inactivation of mutant p53 expression at either initial or delayed phases of tumorigenesis. Specifically, the inactivation of p53 as a single event results in the installation of expression signatures alliance with enhanced proliferation rate [207-209]. In comparison, inactivating p53 in concomitance with oncogenic H-Ras expression stimulates a large set of chemokines and interleukins that endorsed angiogenesis, invasion, and metastasis [210, 211]. These data support the hypothesis that Tp53 mutations at initial stages of tumourigenesis accord mainly to unbounded proliferation, a component of both benign and malignant tumors, whereas alterations at later phase in harmony with further oncogenic acts to drive invasion and metastasis, the hallmark and indication of malignant tumors [195]. 


\section{Biomarkers for oral cancer}

Using the electrochemical procedure, we can recognize the biomarker for oral cancer. The serum level of cytokeratin fragment-21-1 (Cyfra-21-1) was measured to determine whether the cells are associated with epithelial cell cancers or not. Nanoparticles containing cerium oxide nanotubes and graphene oxide $\mathrm{GO}$ (ncCeO2-RGO) are used in this field. In situ reduction of GO is done to get the nanoparticles of cerium oxide and reduced GO. The reaction is carried out in the presence of a hydrazine hydrate. Reduced GO is highly conductive, and this property helps make it the perfect material to form nanoparticles and hence can be used electrochemically along with cerium oxide for the detection of cancers. The cerium oxide nanotubes provide a large surface area to volume ratio for additional surface adjustment by anti-Cyfra-21-1, resulting in the nanoparticles' synergistic property. This immune sensor shows the particular disclosure of cytokeratin piece $21-1$ from $0.625 \mathrm{pg} \mathrm{ml}^{-1}$ to $15 \mathrm{ng} \mathrm{ml}^{-1}$, most decreased affirmation limit $0.625 \mathrm{pg} \mathrm{ml}^{-1}$ with all-inclusive affectability $14.54 \mu \mathrm{A} \mathrm{ng}^{-1} \mathrm{ml} \mathrm{cm}^{-2}$. Moreover, this immune sensor can check the cytokeratin section 21-1 in saliva tests as recorded by the unprecedented reaction with the spiked models [111].

This is basic criteria for the use of graphene oxide in the treatment of oral malignancy as it was declared that the treatment of graphene oxide limited Wnt signaling and Notch-driven signaling, and furthermore signal transducer and activator of transcription proteins $1 / 3$ (STATs) signaling and the atomic factor erythroid 2-related factor 2 (NRF2)- subordinate cell reinforcement reaction, while the little effect was seen on changing development factor$\beta /$ SMAD-signaling [112]. Regardless, several investigations in this field have been represented. Usage of graphene oxide in the treatment of oral malignant growth has been represented by Kumar et al., who explored the production of a non-obtrusive, without a mark and capable biosensing stage for the disclosure of the biomarker CYFRA-21-1 in oral malignant growth [113]. They proposed using a zirconium oxides-decrease graphene oxide nanomaterial for looking at the effect of zirconium oxides nanoparticles. Additionally, the movement of neutralizer antigen-acting master trades in the presentation of this immunosensor. Thusly, more spotlight on such uses could give positive results in treating oral threat and malignancy [113].

The nitrogen-doped graphene oxide was applied in anticancer prescription transport and performed both in vivo and in vitro endeavors. In their appraisal, the impacts of ligand thickness on amazing tumors focusing on the limit of nitrogen-doped graphene oxide were assessed utilizing folate as a model ligand. KB cells demonstrated that developing ligand thickness genuinely broadened the cell take-up of nitrogen-doped graphene oxide, yet in vivo data of tumor assortment of nitrogen-doped graphene oxide exhibited a low fundamental ligand thickness. The higher tumor assortment of nitrogen-doped graphene oxide by ligand conjugation over the essential concentrate also improves photothermal tumor evacuation in vivo. Notwithstanding in vitro results, they ensure the powerful usage of nitrogen-doped graphene oxide as a drug transport device for disease treatment [114].

Platinum (Pt) stacked graphene quantum speck composite (GPt), changed through polyethylene glycol (PEG), can upgrade the oral threat (oral squamous cell carcinoma) chemotherapeutic effectuality. Platinum stacked graphene quantum dab composite could upgrade the repression in the Synthesis period of the cell cycle and lead to cell apoptosis. It possibly increases the platinum swelling in both normoxia and hypoxia (province of oxygen commonality) conditions inside cells. The in vivo yield offered by Platinum stacked graphene 
quantum speck composite uncovered that Platinum stacked graphene quantum dab composite could be a model for original composite for malignancy healing treatment by coordinating the pharmacopeia of the medication for higher tumefaction accumulation and marginally limiting fundamental poisonousness. Subsequently, the consolidated nanoparticle conveyance is relied upon to have expanded clinical use in the blink of an eye treatment of malignant growth [115]. Furthermore, biocompatible Graphene oxide is used alongside an azo-sweet-smelling compound. Strong Polyvinyl liquor (PVA) hydrogels encompassed by curcumin GO-N=NGO/PVA were seen as sheltered in the stomach, expanding the colon-focusing on ability and abiding time inside the colon. Accordingly, these hydrogel composites are relied upon to treat colorectal disease with high profitability and lower harmfulness [116].

\section{Applications of graphene and its composite nanoparticle}

Nanoparticles have been used in numerous fields used in various branches of science and engineering. Basically, used as a modification and to enhance activity such as electrical, optical, and biological. Nanotechnology is widely used in our day-to-day life, including its use in medicine. Using nanotechnology, we can analyze and also can manipulate atoms, chemical bonds, and molecules present in different compounds. Various types of nanoparticles are used in nano dentistry. Nanomaterials are used in toothpaste and other rinsing solutions for better oral healthcare services. Nanomaterials are used in the dental filling, polishing of the enamel surface to prevent cavities. It is also used as implant materials that are more effective than the other conventional materials. Some of the nanoparticles act as antimicrobial agents to prevents bacterial growth. Therefore, nanodentistry attracts patients to dentistry because of its costeffective, time-saving technique and preventing mental trauma. In this study, below are some of the particles used. Graphene and its composites are versatile materials with various characteristic features such as large surface area and high mechanical properties and can be transferred or deposited onto different substrates. The combination of these composite materials with different compositions, structures, and properties can result in composites with tailored physical and chemical characteristics and modified mechanical properties or bioactivity. Due to its enhanced capabilities, composites are widely used in dentistry and other biomedical areas.

GO and rGO act as antimicrobial carriers providing development against many strains of microorganisms and cause the least cytotoxic and oxidative damage. This can also be used as cancer treatment agent. It is found to be used with the biomaterial to enhance the bioactivity of the materials resulting in better output. Other agents which work as antibacterial and performing antimicrobial activity are GO-Ag nanoparticle (NPs), GO- $\mathrm{Ag}_{3} \mathrm{PO}_{4} \mathrm{NPs}$, G-AgNPsPA, rGO-Ag NPs-PDDA (antibacterial), GO-AgNPs PDA NPs, G-AgNPs/PEI, rGO-PEIAgNPs- $\mathrm{Fe}_{2} \mathrm{O}_{3}$, rGO-Ag-CoFe ${ }_{2} \mathrm{O}_{4}$, rGO-Ag-CoFe $2 \mathrm{O}_{5}$, GO-Ag NPS-PAA, GO-Ag- $\mathrm{TiO}_{2}$ (prevent infection and has antibacterial activity), minocycline hydrochloride-GO-Ti NPs (antibacterial) (Table 2). The main composition is GO (Graphene Oxide) which on addition with different nanoparticles form different product and give additional benefits, and the reduced graphene oxide (rGO) has several properties teeth implants, oral cancer treatment, good anti-microbial components, and imaging, restrain the development of E. coli, S. aureus, B. subtilis and also used in titanium dental implants, membranes for bone regeneration, resins, cements and adhesives, tooth whitening procedure and enhance bioactivity of biomaterials, tissue-engineering [133-147]. 
Table 2. Applications and advantages of graphene oxide and composite nanoparticles.

\begin{tabular}{|c|}
\hline Nanoparticles \\
\hline $\mathrm{GO}$ and $\mathrm{rGO}$ \\
\hline GO-AgNPs \\
\hline GO-Ag $\mathrm{AO}_{4} \mathrm{NPs}$ \\
\hline rGO-AgNPs \\
\hline rGO-ZnO \\
\hline
\end{tabular}

Functions

Teeth implants, a biomarker in oral cancers, good anti-microbial activity, hydrophobic material, cause oxidative damage, cytotoxic nature, induced least amount of damage to the dental follicle, decrease dental pathogens, acts as an adsorbing agent, up regulate expression of beta-catenin protein and activate catenin/wnt signaling pathway, increase the degree of proliferation and differentiation of cultured cells and led to the acceleration of bone formation, graphene form derivatives with titanium and utilized in dental implants, bone regeneration, resins, cements and adhesives, tooth whitening procedure etc. Antibacterial Acts as biomaterials, inhibit corrosion, antibacterial agent, light-sensitive agent Action is faster than GO, increase activity of GO NPs

Oral cancer biomarker with $\mathrm{nCeO} 2-\mathrm{rGO}$ and as reinforcement materials to commercial glass-ionomers cements (GIC)

\begin{tabular}{l|l}
$\mathrm{GO}-\mathrm{ZnO}$ & Graphene/zinc oxide nanocomposite (GZNC) forms a biofilm, teeth, fracture-resistant and
\end{tabular} low-density property is suitable for implantation.

\begin{tabular}{|c|c|}
\hline GO-CdS & $\begin{array}{l}\text { The CdS/RGO composite material can be used as a gas sensor for } \mathrm{CO}_{2} \text { based on its } \\
\text { electrocatalytic behavior. }\end{array}$ \\
\hline $\mathrm{rGO}-\mathrm{Cu}_{2} \mathrm{O}$ & Antibacterial and $\mathrm{CO}_{2}$ reduction without the need for a noble-metal co-catalyst. \\
\hline $\mathrm{GO}-\mathrm{Fe}_{3} \mathrm{O}_{4}$ & Antibacterial, Photosensitive \\
\hline $\mathrm{GO}-\mathrm{Fe}_{2} \mathrm{O}_{3}$ & $\begin{array}{l}\text { GO-Fe2O3 hybrid material can act as an efficient heterogeneous catalyst for the } \\
\text { degradation of organic contaminants, which may provide insight into the design and } \\
\text { development of high-efficiency visible-light photocatalysts for water treatment. }\end{array}$ \\
\hline $\mathrm{GO}-\mathrm{MnFe}_{2} \mathrm{O}_{4}$ & $\begin{array}{l}\text { Use for adsorptive removal of } \mathrm{Pb} 2+\text { ions from the aqueous medium, low-cost adsorbents } \\
\text { for fast and effective removal of arsenic from water, the recyclable catalyst for the } \\
\text { reduction of p-nitrophenol }\end{array}$ \\
\hline $\mathrm{GO}-\mathrm{Bi}_{2} \mathrm{WO}_{6}$ & Photocatalytic activity \\
\hline G-AgNPs-PA & Antibacterial and antioxidant \\
\hline rGO-Ag NPs-PDDA & $\begin{array}{l}\text { Antibacterial widely used in various applications such as wastewater treatment plants and } \\
\text { various biological and medical applications }\end{array}$ \\
\hline G-AgNPs/PEI & $\begin{array}{l}\text { Antibacterial, cell culture for weakly anchoring cells, cationic polymer, carbon dioxide } \\
\text { capture, and separation }\end{array}$ \\
\hline rGO-PEI-AgNPs-Fe $2 \mathrm{O}_{3}$ & Antibacterial \\
\hline rGO-Ag-CoFe $2 \mathrm{O}_{4}$ & Anticancer, antibacterial \\
\hline $\mathrm{rGO}-\mathrm{Ag}-\mathrm{CoFe}_{2} \mathrm{O}_{5}$ & Anticancer, antibacterial \\
\hline GO-Ag NPS-PAA & $\begin{array}{l}\text { Antimicrobial prop enhance, disposable diapers, ion exchange resins, adhesives, detergents, } \\
\text { acrylics, }\end{array}$ \\
\hline GO-Ag NPs-PDA & $\begin{array}{l}\text { Wound dressing application, antimicrobial, and polymer, coating material, adsorbents } \\
\text { coating in biomedical science }\end{array}$ \\
\hline GO-Ag-Ti & Antibacterial, inhibit implant-related infections and electrophoretic deposition, \\
\hline hydrazine hydrate & Acts as a reducing agent, oxygen scavenger, source of drug hydralazine in Anti TB, as fuel \\
\hline polyethylene glycol & Polymer, making dental material, fillings, bio film formation, or implants \\
\hline $\mathrm{ncCeO}_{2}-\mathrm{RGO}$ & $\begin{array}{l}\text { Great selectivity, affectability, strength, and reusability with high electrocatalytic } \\
\text { movement toward paracetamol and sensitive electrochemical sensor, protect human dental } \\
\text { stem }\end{array}$ \\
\hline Hydroxyapatite/GO NPs & $\begin{array}{l}\text { Orthopedic, dental research } \& \text { treatment has biological compatibility, defensive layers for } \\
\text { dentistry against erosive procedures, fillers in dental or orthopedic applications too }\end{array}$ \\
\hline $\begin{array}{l}\text { Platinum }(\mathrm{Pt}) \text { loaded-graphene } \\
\text { quantum dot composite, } \\
\text { modified via polyethylene } \\
\text { glycol }\end{array}$ & $\begin{array}{l}\text { Enhance the oral malignancy (oral squamous cell carcinoma) chemotherapeutic } \\
\text { efficaciousness enhance the confinement in the Synthesis phase of cell cycle and lead to } \\
\text { cell apoptosis, potentially raises the platinum inflation in both normoxia and hypoxia (state } \\
\text { of Oxygen normalcy) conditions inside cells, cancer remedial treatment therapy, treatment } \\
\text { of cancer. Catalytic ozonation, dental restorations and provide strengths and stiffness }\end{array}$ \\
\hline $\mathrm{GO}-\mathrm{N}=\mathrm{N}-\mathrm{GO} / \mathrm{PVA}$ & $\begin{array}{l}\text { Increase colon targeting capability \& dwelling time inside the colon and hence colorectal } \\
\text { cancer. Filling, antibacterial }\end{array}$ \\
\hline Paracetamol & Toothaches, fever, aches in dentistry \\
\hline Hydrogen peroxide cobalt & Bleaching and antiseptic \\
\hline tetra phenyl porphyri & uction of singlet $\mathrm{o}$ \\
\hline
\end{tabular}




\begin{tabular}{l|l}
\hline Nanoparticles & Functions \\
\hline $\begin{array}{l}\text { anti-toxin minocycline } \\
\text { hydrochloride }\end{array}$ & Tetracycline antibiotic used to treat bacterial infections \\
\hline $\begin{array}{l}\text { Minocycline hydrochloride- } \\
\text { GO-Ti }\end{array}$ & Antibacterial, stimulate the human gingival fibroblast cells proliferation in vitro \\
\hline $\begin{array}{l}\text { cerium oxide nanocubes with } \\
\text { rGO }\end{array}$ & $\begin{array}{l}\text { Great selectivity, affectability, strength, and reusability with high electrocatalytic } \\
\text { movement toward paracetamol, sensitive electrochemical sensor, rescue human dental stem }\end{array}$ \\
\hline Sodium- Titanium substrate & $\begin{array}{l}\text { Periodontal ligament stem cells expansion with GO, regenerative dentistry, } \\
\text { Biocompatibility, corrosion, strength, }\end{array}$ \\
\hline G-Ag- $\mathrm{TiO}_{2}$ & Antibacterial, antimicrobial
\end{tabular}

Some of the composites along with antimicrobial activity, work as a treatment for cancer; such composites provide additional benefits to overcome infections and diseases. Some of the examples arerGO-PEI-AgNPs- $\mathrm{Fe}_{2} \mathrm{O}_{3}, \mathrm{rGO}-\mathrm{Ag}-\mathrm{CoFe}_{2} \mathrm{O}_{4}, \mathrm{rGO}-\mathrm{Ag}-\mathrm{CoFe}_{2} \mathrm{O}_{5}$, etc. GO$\mathrm{N}=\mathrm{N}-\mathrm{GO} / \mathrm{PVA}$ helps in increasing colon targeting capability and dwelling time inside the colon and improves colorectal cancer. GO-Ag nanoparticles can also be used in toothpaste so it can prevent further infection in teeth. Hydrogen peroxide cobalt-tetraphenyl porphyrin /rGO has an important role in dental treatment such as bleaching, mild antiseptic, relief mouth irritation, gingivitis, dentures. $\mathrm{ZnO}$ is mainly used as temporary fixing contents and filling materials for gingival dressings and, together with filling materials, as impression materials. Compounds viz. paracetamol (PCM) helps to cure toothaches in dentistry and fever. The $\mathrm{ncCeO}_{2}-\mathrm{RGO}$ with great selectivity, affectability, strength, and reusability showed high electrocatalytic movement toward paracetamol [148-151].

Infection is the most common activity performed by the cosmopolitan micro-organism, causing a biofilm formation over the decay. Graphene/zinc oxide nanocomposite (GZNC) has the potential to the biofilm caused by $S$. mutans. Acrylic teeth coated with graphene are used due to their cost-effectiveness, fracture-resistant, and low-density properties are suitable for implantation [152]. Hydroxyapatite/GO NPs are used for treatment in different orthopedics, medicine transfer, dental researcher \& treatment, has biological compatibility, defensive layers for dentistry against erosive procedures. Also, work as fillers in dental or orthopedic applications too and during the process of metabolism, as some ROS (reactive oxygen species) are produced within the body, which could lead to harmful output. Hydrazine hydrate acts as a reducing agent, oxygen scavenger, and a source of drug hydralazine in Anti TB. Polyethylene glycol, GO-Ag NPs-PDA with the application as wound dressing, antimicrobial, polymer, coating material, adsorbents coating in biomedical science, making dental material, fillings, biofilms formation. Also, Platinum (Pt) loaded-graphene quantum dot composite, modified via polyethylene glycol, enhance the oral malignancy (oral squamous cell carcinoma) chemotherapeutic efficaciousness enhance the confinement in the synthesis phase of the cell cycle and lead to cell apoptosis, potentially raises the platinum inflation in both normoxia and hypoxia (state of oxygen normalcy) conditions inside cells, cancer remedial treatment therapy, treatment of cancer. Catalytic ozonation, dental restorations and provide strengths and stiffness $[153,154]$.

$\mathrm{GO}-\mathrm{Fe}_{2} \mathrm{O}_{3}$ hybrid material can act as an efficient heterogeneous catalyst for the degradation of organic contaminants. It may provide insight into the formulation and development of high-efficiency visible-light photocatalysts for dental treatment. The applications of PDT (Photodynamic therapy in dentistry) in dentistry are growing rapidly to treat oral cancer and microbial infections. The lack of genotoxic and mutagenic effects of PDT is an important factor for long-term safety during treatment. PDT also represents a novel 
therapeutic approach in the management of oral biofilms as well. The photodynamic diagnosis (PDD) is more helpful in assessing the malignant transformation of oral lesions. Photodynamic antimicrobial chemotherapy (PACT) has profound potential to treat bacterial, fungal, parasitic, and viral infections. Thus, the oral cavity is especially suitable for PACT because it is relatively accessible to illumination $[155,156]$. Since $S$. mutans that cause dental caries can easily adhere to the tooth surface or orthodontic devices attached to tooth surfaces, the anti-adhesion effect of photocatalytic $\mathrm{TiO}_{2}$ was monitored [157]. The electrostatic interaction in nanoparticles makes it easy to uptake by cell walls, leading to its disintegration [158]. The large volume of these nanoparticles penetrates the cell membrane [159]. This mechanism beholds the basic criteria to use such nanoparticles to acts as an antibacterial and can be used in various medical fields [160].

\subsection{Tooth erosion.}

So, a multi-walled carbon nanotube with graphene oxide ties with nano-hydroxyapatite seemed to outline a cautious layer for dentistry against erosive methodology. Dentistry treatment with nano-hydroxyapatite achieved extended part carbonate in light of a possible relationship with counterfeit salivation. Acidulated phosphate fluoride gel treatment identified with multi-walled carbon nanotube with graphene oxides or nano-hydroxyapatite/multi-walled carbon nanotube with graphene oxides covering reduced the band region identified with the normal material. This could have happened by surrounding an additional limit, which lessened regular framework introduction. SEM micrographs showed that after erosive cycling, the dentin compensated with acidulated phosphate fluoride and secured with hydroxyapatite/multiwalled carbon nanotube with graphene oxides held some degree of spread. This suggests by talking with the dentin, the covering falsely connects to dentin, subsequently making sure about it during deterioration cycles. Nano-hydroxyapatite, multi-walled carbon nanotube with graphene oxides and nano-hydroxyapatite/multi-walled carbon nanotube with graphene oxides-secured acidulated phosphate fluoride dentin extended the carbonate/phosphate extent and ensured the dentistry against erosive masters (Electrochemical impedance spectroscopy assessment). These revelations showed that the unfaltering quality of nano-hydroxyapatite and multi-walled carbon nanotube with graphene oxides following erosive cycling was likely associated with the headway of a destructive safe surface film and the previous utilization of fluoride invigorated this correspondence (explored by Electrochemical impedance spectroscopy). We recognize somewhat the invalid theory attempted here that the biggest differences were in normal substance and morphology of dentistry for each inspected item [117].

\subsection{Tooth aches.}

In the diagram, the amalgamation of the outstandingly specific and delicate electrochemical recognizing of paracetamol using nanosized cerium oxide nanoparticles adorned with diminished graphene nanocomposite modified anode was represented. The PM sensor shows a wide straight extent of $0.05-0.600 \mu \mathrm{M}$ with identification just as affectability limit $(\mathrm{S} / \mathrm{N}=3) 0.0092 \mu \mathrm{M}$ and $276 \mu \mathrm{A} \mu \mathrm{M}^{-1} \mathrm{~cm}^{-2}$, independently. The nanosized cerium oxide with diminished graphene oxide nanocomposite is found to have incredible selectivity, affectability, quality, and reusability with the high electrocatalytic development toward paracetamol. The proposed methodology for explicit acknowledgment of paracetamol in 
different examples tests with incredible recoveries can be adequately applied here. Such an investigation will point of fact prepare for the disclosure of bleeding-edge paracetamol sensors that could be inserted for industrious seeing of paracetamol run through different body liquids [118].

\subsection{Tooth bleaching.}

We picked four sorts of recoloring (D\&C Red No.17, D\&C Red No.34, D\&C Red No.36, and D\&C Orange No. 4), 3 sorts of lighting up (hydrogen peroxide alone, hydrogen peroxide cobalt-tetra phenyl porphyrin, and hydrogen peroxide cobalt-tetraphenyl porphyrin/decreased graphene oxide) and 3 separate light sources (not photo lit up, photo lit with $245 \mathrm{~nm}$, and photo lit with $310 \mathrm{~nm}$ ), on account of the disclosures of this investigation, cobalt-tetra phenyl porphyrin, and Hydrogen peroxide cobalt- tetraphenyl porphyrin/diminished graphene oxide nanocomposite was used as a gadget for dental whitening, and it basically extended the blurring viability of hydrogen peroxide [119].

\subsection{Membranes in dental.}

To improve the general capacity of guided bone regeneration (GBR) layers in an oral medical procedure (surgery), the expansion of graphene must improve the capacity of the film to keep delicate tissue cells from penetrating the developing bone [120]. The expansion of graphene must do this while additionally holding fast to the five standards underlines by Scantlebury: biocompatibility, space-production, tissue joining, and clinical sensibility [121]. While advancing collagen films with graphene oxide and testing its impact on human gingival fibroblasts, the nearness of graphene oxide on collagen layers brought about lower deformability, decreased hydration, higher firmness, and expanded unpleasantness in contrast with non-covered layers. Following three days of culture and the encouraged attachment of proteins to the film, it was found that these progressions made by the graphene oxide on collagen evaded any sort of provocative reaction and generally preferred the multiplication of human gingival fibroblasts. The investigations performed with graphene oxide on collagen films were finished utilizing two distinct measures of graphene oxide: one at $2 \mu \mathrm{gml}^{-1}$ and one at $10 \mu \mathrm{gml}^{-1}$, both making the equivalent previously mentioned valuable outcomes to human gingival fibroblasts [122]. When applied to human dental pulp stem cells, graphene oxide covering on collagen films is found to render cells incapable of entering into the layer, while the more focused graphene oxide covering brings about the development of a thicker cell layer. These disclosures are made through hematoxylin-eosin recoloring. Graphene oxide covering of collagen layers is likewise resolved to advance the procedure of osteoblastic separation, to be perfect with cell suitability in a portion subordinate way, and to diminish irritation $[122,123]$. Once more, even though it appears to be truly conceivable that these graphene oxides covered films can be utilized to improve or supplant the current guided bone regeneration layers utilized in dental, various conditions have ecological variables that ought to be considered before arriving at an authoritative resolution on the use of graphene in layers.

\subsection{Inhibition of bacteria biofilms.}

Microscopic organisms' biofilms accept imperative employment in dentistry pathogenic frameworks because of their capacity to endure through different standard 
antibacterial administrators. Thusly, it is pivotal to find productive techniques to quell the creation of biofilms. Starting late, Zisheng Tan and his partners confirmed that graphene oxide nanosheets could productively subdue $S$. mutans biofilm game plan over a wide extent of obsessions during the beginning events of the bacterial biofilm advancement $(0-4 h)$. Peculiarly, because of creating biofilms (six hours), graphene oxide had only an irrelevant impact [124]. They found that intertwining graphene oxide to a making film could limit the connection and activity of bacterial cells during the starting season of biofilm course of action, and graphene oxide was stunning in slaughtering the $S$. mutans organisms. Additionally, the sheet-like structure of graphene oxide could conjugate with cells to shape a representing inorganic utilitarian layer, which influenced the capacity of the minute living beings to transmit extracellular polymeric substances. This is basic as extracellular polymeric substance accepts a basic protective activity in the association approach and restriction against antimicrobial experts. The low extracellular polymeric substance will instigate less troublesome destruction of the encircling movies. Wretchedly, inferable from the bountiful extracellular polymeric substance released, organisms that create biofilms are less tricky to the proximity of graphene oxide. Finally, the obtained delayed consequences of their work showed that graphene oxide nanosheets are astounding in hindering and compensating oral contaminations by encroaching with the game plan of bacterial biofilms [124].

\subsection{Implants.}

Ti embeds are starting at now seen as the best exchange for the regular tooth in light of how they have positive biocompatibility are strong and obvious. Nevertheless, titanium's naturally dormant quality leaves it feeble to impelling the improvement of strong tissue. This can make the insert miss the marks making titanium implants the best other option yet open to advance $[125,126]$. The structure of an endosseous implant is made out of a device that is put on the bone, close by a projection screwed to the most noteworthy purpose of the establishment and the upper prosthesis, as ousted. Graphene oxide-Titanium embeds were made considering the recently referenced preferred position of graphene oxide - covering concerning human dental mash immature microorganisms. Each way that the additions were made, they demonstrated that graphene oxide-covering of Titanium embeds make, for the most part, an improved favorable position over Titanium inserts alone. These improvements are generally concerning cell osteogenic division and the biocompatibility and cell development of the supplements [127-129]. Graphene oxide-covering of Titanium embeds also exhibited antibacterial properties on these supplements, most sufficiently when the graphene oxide covering is functionalized with antibacterial substances, for instance, silver nanoparticles and against contamination operators. Exactly when gotten together with the serum poison minocycline hydrochloride, the graphene oxide-covering improves the antibacterial activity against facultative anaerobic or overwhelming infinitesimal living beings due to the synergic effect of minocycline release butchering and graphene oxide contact-killing. Graphene oxidesilver covering on Ti has been exhibited to be helpful against Porphyromonas gingivalis and Streptococcus mutans. It would then have the option to be found that the graphene oxide covering with hostile to contamination specialists or silver on Titanium embeds improves the antibacterial attributes of the Titanium embeds, shielding infections from developing in light of the implant being used in the patient $[127,130,131]$. 
Even though graphene oxide-covering with these particular nanocomposites have antibacterial effects against practically identical and different sorts of infinitesimal creatures depending whereupon is used, it will, in general, be settled that a graphene oxide - covering of Titanium embeds with one of these nanocomposites would be an improvement to the standard Titanium insert. These improvements may have the alternative to broaden when considering the limit of periodontal tendon foundational microorganisms to fill in as a choice instead of bone marrow mesenchymal stem cells referenced previously. Periodontal tendon immature microorganisms energize the use of graphene oxide as a strong canvas on which to shape the structure and limit of these periodontal tendon undifferentiated cells. Periodontal tendon foundational microorganisms seeded onto graphene oxide-secured stages show a higher extension rate than on graphene oxide alone, and a Sodium-Titanium substrate is useful as well. Wrapped up from this is the way that a mix of periodontal tendon foundational microorganisms, graphene oxide, and Sodium-Titanium can make many remembered overhauls and points of interest for the field of regenerative dentistry [132]. Thus, likewise with the rest of graphene and graphene-based nanomaterials' applications in dentistry, the reaching out of these points of interest from systems to embed in a regenerative manner ought to be furthermore perused and gone after for undeniable favorable circumstances to result [127]. Graphene has various possible focal points to embed in dentistry, regardless, the nanoparticles that it is joined with, and the biological components of each patient's oral gap must be considered for every circumstance before any further measure is taken.

\section{Comparison of various nanoparticles}

Various kinds of nanoparticles are being used with their distinct functions such as antimicrobial activity, cancer treatment, drug delivery, use of biomaterial for bone and tooth replacement [161]. A comparison of these nanoparticles can be analyzed in terms of their efficacy, application, cost etc. Working efficacy and cost play a major role when these nanoparticles are used in medicine [161,162]. Accordingly, the cost and applications of some nanoparticles that impart an important role in antimicrobial activity are compared and analyzed with those of others. As suggested, GO-AgNPs have wide application for antibacterial activity and are cheap as compared with the other, i.e., GO- $\mathrm{Ag}_{3} \mathrm{PO}_{4} \mathrm{NPs}[161,163]$. In accordance with it, $\mathrm{rGO}-\mathrm{AgNPs}$ and $\mathrm{rGO}-\mathrm{Cu}_{2} \mathrm{O}$ both have a similar activity that of antimicrobial, but when compared to both with their cost rGO-AgNPs are much cheaper [164]. As proposed, G-AgNPsPA, G-AgNPs/PEI, and G-Ag- TiO2 have similar functions with antimicrobial activity, while G-AgNPs/PEI is the cheapest among these three. The rGO-Ag NPs-PDDA, rGO-PEI-AgNPs$\mathrm{Fe}_{2} \mathrm{O}_{3}, \mathrm{rGO}-\mathrm{Ag}-\mathrm{CoFe}_{2} \mathrm{O}_{4}, \mathrm{rGO}-\mathrm{Ag}-\mathrm{CoFe}_{2} \mathrm{O}_{5}$ were compared for their efficacy as well as cost, as analyzed rGO-PEI-AgNPs-Fe ${ }_{2} \mathrm{O}_{3}$ was cheapest among all while $\mathrm{rGO}-\mathrm{Ag}-\mathrm{CoFe}_{2} \mathrm{O}_{4}$, as well as rGO-Ag-CoFe2O5, were of similar price with almost equal efficacy [165]. Similarly, some other nanoparticles were compared with each other where GO-Ag NPs-PDA was found to be the cheapest compared with these three nanoparticles $\mathrm{GO}_{-}-\mathrm{Fe}_{3} \mathrm{O}_{4}, \mathrm{GO}-\mathrm{Ag}$ NPS-PAA, and GOAg-Ti.As suggested, hydrazine hydrate, anti-toxin minocycline hydrochloride, and minocycline hydrochloride-GO-Ti were observed, that hydrazine hydrate was compared with each other cheapest among of these three. As proposed, hydrazine hydrate was found to be the cheapest of all nanoparticles mentioned above for antimicrobial activity. Some of the nanoparticles or nanomaterials have great significance in dentistry, Orthopedic, wound dressing, etc. [166]. These include GO, rGO, GO- $\mathrm{Ag}_{3} \mathrm{PO}_{4}$ NPs, rGO-AgNPs, GO-ZnO, GO- 
Ag NPs-PDA, polyethylene glycol, Hydroxyapatite/GO NPs, Sodium- Titanium substrate. As proposed, comparing and rGO, both of these have an exactly similar function in dentistry, but when compared in cost, the GO is much cheaper than that of $\mathrm{rGO}$, and while compared with rGO-AgNPs, it is much more costly than GO and rGO. In accordance with it, similarly, GO$\mathrm{Ag}_{3} \mathrm{PO}_{4} \mathrm{NPs}, \mathrm{GO}-\mathrm{ZnO}, \mathrm{GO}-\mathrm{Ag}$ NPs-PDA were compared in terms of their wide application as well as cost. It was observed that all three are widely used in fracture or tooth implantation, but when compared to cost, GO-ZnO is the cheapest than all three mentioned here [167]. A wide application of nanoparticles is marked in cancer treatment via targeted drug delivery or by other means. Various nanoparticles used for cancer treatment are rGO-ZnO, rGO-Ag-CoFe2O5, GAgNPs/PEI, Platinum (Pt) loaded-graphene quantum dot composite, modified via polyethylene glycol, GO-N=N-GO/PVA, Minocycline hydrochloride-GO-Ti, etc. [168-169]. As suggested when compared these, all minocycline hydrochloride-GO-Ti is much of cost which may be far away from the use of the middle-class person. At the same time, Platinum (Pt) loaded-graphene quantum dot composite, modified via polyethylene glycol, has wide application, i.e., used as a chemotherapeutic agent for the treatment of colon cancer and is cheap, so it is among the reach common people.

\section{Emerging therapeutic approaches}

The oral cancer biomarker can be identified by using the technique electrochemically, which are cerium oxide nanocubes reduced graphene oxide (ncCeO2-RGO)-based nanoparticles. These nanoparticles were developed by the in situ reductions of GO, in the existence of cerium oxide nanocubes utilizing hydrazine hydrate. For the electrochemical detection, these nanoparticles are ideal products as reduced graphene oxide and cerium oxide enable the quick exchange of electrons due to the high conductivity of reduced graphene oxide, and cerium oxide nanocubes provide a high surface to volume ratio for additional surface alteration by anti-cyfra-21-1 and improved efficient synergist properties. The particular discovery of cytokeratin fragment-21-1 from $0.625 \mathrm{pg} \mathrm{mL} 1$ to $15 \mathrm{ng} \mathrm{mL} 1$, most reduced recognition limit $0.625 \mathrm{pg} \mathrm{mL}-1$ with the expanded affectability $14.54 \mu \mathrm{A} \mathrm{ng}-1 \mathrm{~mL} \mathrm{~cm}-2$ was displayed on these immunosensors with addition to the checking on the cytokeratin fragment in saliva tests as saw by the great reaction with the spiked samples [212,213]. It is known for its significant potential to treat oral cancer. It was later reported that the treatment of graphene oxide restrained Wnt signaling, Notch-driven signaling, and signal transducer and activator of transcription proteins 1/3 (STATs) signaling [214]. It has little impact on the nuclear factor erythroid 2- related factor 2 (NRF2) - dependent antioxidant response and transforming growth factor- $\beta /$ SMAD- signaling as well [214]. For the treatment of oral cancer, utilization of graphene oxide has been accounted for by Kumar et al. [215], who worked and researched on the manufacture of a non-invasive, mark-free, and proficient biosensing stage for the discovery of the biomarker CYFRA-21-1 in oral cancer. He proposed that the utilization of zirconium oxides-reduce graphene oxide nanomaterial for the assessment of the impact of zirconium oxides nanoparticle also, the job of antibody-antigen acting agent communications in the presentation of this immunosensor. Thereafter, more spotlight on these kinds of utilization could determine positive results for the treatment of oral cancer [212,215].

Nitrogen-doped graphene oxide can also be used in anticancer medication conveyance and is conducted both in vivo and invitro tries. The impacts of ligand thickness on dynamic tumours focussing on the potential of nitrogen-doped graphene oxide were evaluated by 
utilizing folate as a model ligand in the assessment. It was indicated in the KB cells that upon expanding the ligand thickness, the cell take-up of nitrogen-doped graphene oxide also expanded directly, yet in vivo information of tumor collection of nitrogen-doped graphene oxide determined a low basic ligand thickness. The better photothermal tumor removal in vivo is brought by the higher tumor collection of nitrogen-doped graphene oxide by the ligand conjugation over the basic focus additionally. Barring the invitro outcomes, they guarantee the effective utilization of nitrogen-doped graphene oxide as a medication conveyance apparatus for cancer therapy $[212,216]$.

Platinum (Pt) loaded-graphene quantum dot composite (GPt), modified through polyethylene glycol (PEG), has the potential to augment the oral malignancy (oral squamous cell carcinoma) chemotherapeutic efficaciousness. Platinum loaded-graphene quantum dot composite could elevate the confinement in the Synthesis phase of the cell cycle, leading to cell apoptosis which levels up the platinum inflation in both normoxia and hypoxia (state of oxygen normalcy) conditions inside the cells. In vivo output result by platinum loadedgraphene, quantum dot composite showed that cancer remedial treatment therapy directed the pharmacopeia of the drug for higher tumefaction amassment and slightly minimized systemic toxicity. Thus, in the near future, it is expected that the incorporated nanoparticle delivery has enlarged clinical utilization $[212,217]$. Also, the utilization of biocompatible graphene oxide along with azo-aromatic compound and potent polyvinyl alcohol (PVA) hydrogels surrounded by Curcumin GO-N=N- GO/PVA was found to be safe in the stomach and therefore, elevating the colon-targeting potential and dwelling time inside the colon. Therefore, these hydrogel composites are expected to treat colorectal cancer with lower toxicity and high productivity $[212,218]$. The experimental techniques consist of the use of sentinel node biopsy for patients with early OCC to characterize the presence of regionally metastatic disease in patients with N0 neck cancer. Some amount of success with this technique and clinical trials will determine its use in treating mucosal malignancies [219]. Various novel agents are under development, such as targeted therapies that affect apoptosis, cell-cycle regulation, gene transcription, transmembrane or intracellular signal transduction, angiogenesis, and invasion [220]. The modest response rates in patients have been demonstrated by most agents, but they also have a novel mechanism of action, enhancing the antineoplastic activity of traditional chemotherapeutic drugs and radiation [222].

Gene therapy and viral therapy techniques are emerging. In one study, patients with incurable HNSCC received Ad-p53 via intratumoral injection. Two patients showed objective tumor regression of greater than $50 \%$, six patients showed stable disease for up to 3.5 months, and nine patients indicated progressive disease [223]. Further investigation is needed for the perfect therapeutic strategy [222, 224]. The expression of mutations in exons of tumor suppression genes can also be defined as a "Premalignant field defect". One such p53 is also a tumor suppressor gene, and mutations of p53 have been observed in different loci or sites of potentially malignant [34]. Oral cancer is a multistep process in which genetic events are altered quantitatively or qualitatively within signal transduction pathways that regulate normal cellular physiology [45-47]. A cancer gene (oncogene) is a gene that enables proteins to transform cells and induce cancer [53]. A few cell oncogenes are homologs of retroviral oncogenes (e.g., the ras genes) and have been involved in oral cancer. [45,55].In early carcinogenesis, transforming growth factor $-\alpha$ (TGF- $\alpha)$ is overexpressed earlier by the hyperplastic epithelium and later by the inflammatory infiltrate, particularly the eosinophils, 
surrounding the invading oral epithelium [72]. In recent research, the largest family of cellsurface molecules, G-protein-coupled receptors (GPCRs), involved in signal transmission, plays an essential role in tumor growth and metastasis [81]. It is well established that inactivation of p53 and interpretation of mutant p53 can support cells with additional growth and survival assets, such as embossed proliferation, prevarication of apoptosis, and chemoresistance [195]. Additionally, the mutant p53 can augment and reinforce cell migration and invasion in vitro assays [200-201]. These data support the hypothesis that TP53 mutations at initial stages of tumourigenesis accord mainly to unbounded proliferation, a component of both benign and malignant tumors, whereas alterations at later phase in harmony with further oncogenic acts to drive invasion and metastasis, the hallmark and indication of malignant tumors [195].

\title{
8. Conclusions
}

Oral cancer is a common type of multistep process cancer that can invade local tissues and cause metastasis. It occurs by causing genetic alterations and environmental influences such as tobacco, alcohol, or viral infection. Tumor suppressor genes activated by genetic events (mutation, deletion, etc.) and oncogenes activated by overexpression (through gene amplification, increased transcription) are the two major types of genetic alterations. The current cancer treatment is basically focused on the different techniques in nanotechnology. It includes the design, characterization, production of nanoscale drug systems. The techniques include the oral cancer biomarker such as cerium and graphene-based, which can be used to identify electrochemically. The nanoparticles are ideal for detecting electrochemically as they give the quick exchange of electrons due to the high conductivity of reducing graphene and cerium oxide Nanocubes. Another nanotechnology technique was by using non-invasive markfree and proficient biosensing using zirconium oxides-reduce graphene oxide nanomaterial. The emerging therapy used is sentinel node biopsy for the patients diagnosed with OCC. It is to be noted that various novel agents are in development that can affect apoptosis, transcription of genes, and regulation of cell cycle with adequate response rates and can also be used simultaneously with chemotherapy and radiation. Further analysis needs to be carried out for an effective therapeutic strategy.

\begin{abstract}
Abbreviations
OSCC, Oral Squamous Cell Carcinoma; OC, Oral Carcinoma; ASR, Age-Standardized Rate; miRNA, Micro-RNA; DNA, Deoxyribo Nucleic Acid; RNA, Ribo Nucleic Acid; CIN, Chromosomal Instability; TSGs, Tumour Suppressor Genes; (TSGs), EGFR, Epidermal Growth Factor Receptor; PRAD-1, Parathyroid Adenomatosis-1; SCC, Squamous Cell Carcinomas; TGF- $\alpha$, Transforming Growth Factor-alfa; PDGF, Platelet-Derived Growth Factors; GPCRs, G-Protein-Coupled Receptors; ARs, Adrenergic receptors; GTP, Guanosine Triphosphate; CCND1, Cyclin D1; BCL-2, B-Cell Lymphoma-2; CAK, Cyclin-dependent Kinase Activating Kinase; TGF- $\beta$; CDK, Cyclin-dependent Kinases; BER, Base Excision Repair; NER, Nucleotide Excision Repair; ROS, Reactive Oxygen Species; MMR, Mismatch Repair; PUMA, p53 Upregulated Modulator of Apoptosis; EMT, Epithelial-Mesenchymal Transition; STATs, Signal Transducer and Activator of Transcription proteins; DDR, DNA Damage Response; ERCC4, Excision Repair Cross Complementing-4; XRCC4, X-ray Repair Cross Complementing-4; NRF-2, Nuclear factor erythroid 2-Related Factor 2; NPs, Nanoparticles; GO, Graphene Oxide; PEG, Polyethylene Glycol; GBR, Guided Bone
\end{abstract}


Regeneration; PDT, Photodynamic Therapy; PDD, Photodynamic Diagnosis; PACT, Photodynamic Antimicrobial Chemotherapy.

\section{Funding}

This research received no external funding.

\section{Acknowledgments}

The authors would like to acknowledge the facilities provided by Maharishi Markandeshwar (Deemed to be University), Mullana-Ambala (Haryana), India, for carrying out this collaborative research work.

\section{Conflicts of Interest}

The authors declare no conflict of interest.

\section{References}

1. Warnakulasuriya, S. Global epidemiology of oral and oropharyngeal cancer. Oral Oncol. 2009, 45, 30916, https://doi.org/10.1016/j.oraloncology.2008.06.002.

2. Tandon, A.; Bordoloi, B.; Jaiswal, R.; Srivastava, A.; Singh, R.B.; Shafique, U. Demographic and clinicopathological profile of oral squamous cell carcinoma patients of North India: A retrospective institutional study. S.R.M. J. Res. Dent. Sci. $2018, \quad 9, \quad$ 114-8, https://doi.org/10.4103/srmjrds.srmjrds_21_18.

3. Shield, K.D.; Ferlay, J.; Jemal, A.; Sankaranarayanan, R.; Chaturvedi, A. K.; Bray, F.; Soerjomataram, I. The global incidence of lip, oral cavity, and pharyngeal cancers by subsite in 2012. CA: Cancer J. Clin. 2016, 67, 51-64, https://doi.org/10.3322/caac.21384.

4. Petti, S.; Masood, M.; Scully, C. The magnitude of tobacco smoking-betel quid chewing-alcohol drinking interaction effect on oral cancer in South-East Asia. A meta-analysis of observational studies. PLoS One 2013, 8, e78999, https://doi.org/10.1371/journal.pone.0078999.

5. Aruna, D.S.; Prasad, K.V.; Shavi, G.R.; Ariga, J.; Rajesh, G.; Krishna, M. Retrospective study on risk habits among oral cancer patients in Karnataka Cancer Therapy and Research Institute, Hubli, India. Asian Pac. J. Cancer Prev. 2011, 12, 1561-6.

6. Rao, S.V.K.; Mejia, G.; Roberts-Thomson, K.; Logan, R. Epidemiology of oral cancer in Asia in the past decade- An update (2000-2012). Asian Pac. J. Cancer Prev. 2013, 14, 5567-77, https://doi.org/10.7314/apjcp.2013.14.10.5567.

7. Koo, K.; Barrowman, R.; McCullough, M.; Iseli, T.; Wiesenfeld, D. Non-smoking non-drinking elderly females: a clinically distinct subgroup of oral squamous cell carcinoma patients. Int. J. Oral Max. Fac. Surg. 2013, 42, 929-33, https://doi.org/10.1016/j.ijom.2013.04.010.

8. Toporcov, T.N.; Znaor, A.; Zhang, Z.-F.; Yu, G.-P.; Winn, D.M.; Wei, Q.; Talamini, R. Risk factors for head and neck cancer in young adults: a pooled analysis in the INHANCE consortium. Int. J. Epidemiol. 2015, 44, 169-85, https://doi.org/10.1093/ije/dyu255.

9. Beena, V.T.; Binisree, S.S.; Ayswarya, T.; Paikkadan, I.; Padmakumar, S.K.; Sivakumar, R. Oral squamous cell carcinoma in patients younger than 40 years: A 10-year retrospective study. Int. J. Sci. Study 2016, 4, 150-3, https://doi.org/10.17354/ijss/2016/395.

10. Feller, L.; Lemmer, J. Oral squamous cell carcinoma: Epidemiology, clinical presentation and treatment. J. Cancer Ther. 2012, 3, 263-8, https://doi.org/10.4236/jct.2012.34037.

11. Chen, Y.K.; Huang, H.C.; Lin, L.M.; Lin, C.C. Primary oral squamous cell carcinoma: An analysis of 703 cases in southern Taiwan. Oral Oncol. 1999, 35, 173-9, https://doi.org/10.1016/s1368-8375(98)00101-8.

12. Bell, R.B.; Kademani, D.; Homer, L.; Dierks, E.J.; Potter, B.E. Tongue cancer: Is there a difference in survival compared with other subsites in the oral cavity? J. Oral Max. Fac. Surg. 2007, 65, 229-36, https://doi.org/10.1016/j.joms.2005.11.094.

13. de Araújo, R.F.; Jr, Barboza, C.A.; Clebis, N.K.; de Moura, S.A.; Lopes-Costa, A. Prognostic significance of the anatomical location and TNM clinical classification in oral squamous cell carcinoma. Med. Oral Patol. Oral. Cirug. 2008, 13, E344-7.

14. Hirata, R.M.; Jaques, D.A.; Chambers, R.G.; Tuttle, J.R.; Mahoney, W.D. Carcinoma of the oral cavity. Ann. Surg. 1975, 182, 98-103, https://doi.org/10.1097/00000658-197508000-00002. 
15. Oliver, A.J.; Helfrick, J.F.; Gard, D. Primary oral squamous cell carcinoma: A review of 92 cases. J. Oral Max. Fac. Surg. 1996, 54, 949-54, https://doi.org/10.1016/s0278-2391(96)90389-4.

16. Mashberg, A.; Merletti, F.; Boffetta, P.; Gandolfo, S.; Ozzello, F.; Fracchia, F.; Terracini, B. Appearance, site of occurrence, and physical and clinical characteristics of oral carcinoma in Torino, Italy. Cancer 1989, 63, 2522-7, https://doi.org/10.1002/1097-0142(19890615)63:12<2522::aid-cncr2820631227>3.0.co;2-x.

17. Jovanovic, A.; Schulten, E.A.J.M.; Kostense, P.J.; Snow, G.B.; Waal, I. Tobacco and alcohol related to the anatomical site of oral squamous cell carcinoma. J. Oral Pathol. Med. 1993, 22, 459-62, https://doi.org/10.1111/j.1600-0714.1993.tb00125.x.

18. Brandizzi, D.; Gandolfo, M.; Velazco, M.L.; Cabrini, R.L.; Lanfranchi, H.E. Clinical features and evolution of oral cancer: A study of 274 cases in Buenos Aires, Argentina. Oral Med. Patol. Cirug. 2008, 13, E5448.

19. Haya-Fernández, M.; Bagán, J.; Murillo-Cortés, J.; Poveda-Roda, R.; Calabuig, C. The prevalence of oral leukoplakia in 138 patients with oral squamous cell carcinoma. Oral Dis. 2004, 10, 346-8, https://doi.org/10.1111/j.1601-0825.2004.01031.x.

20. Holmes, J.D.; Dierks, E.J.; Homer, L.D.; Potter, B.E. Is detection of oral and oropharyngeal squamous cancer by a dental health care provider associated with a lower stage at diagnosis? J. Oral Max. Fac. Surg. 2003, 61, 285-91, https://doi.org/10.1053/joms.2003.50056.

21. Singh, M.; Kumar, V.; Sehrawat, N.; Yadav, M.; Chaudhary, M.; Upadhyay, S.K.; Kumar, S.; Sharma, V.; Kumar, S.; Dilbaghi, N.; Sharma, A.K. Current paradigms in epigenetic anticancer therapeutics and future challenges. Sem. Cancer Biol. 2021, https://doi.org/10.1016/j.semcancer.2021.03.013.

22. Tuli, H.S.; Mittal, S.; Aggarwal, D.; Parashar, G.; Parashar, N.C.; Upadhyay, S.K.; Barwal, T.S.; Jain, A.; Kaur, G.; Salva, R.; Sak, K.; Kumar, M.; Varol., M.; Iqubal, A.; Sharma, A.K. Path of silibinin from diet to medicine: A dietary polyphenolic flavonoid having potential anti-cancer therapeutic significance. Sem. Cancer Biol. 2021, https://doi.org/10.1016/j.semcancer.2020.09.014.

23. A.C.S. Cancer facts and figures. Am. Cancer Soc., Atlanta, GA. 2002.

24. Bijai, L.K.; Mathew, P.; Jayaraman, V.; Austin, R.D. Oral squamous cell carcinoma of palate - A case report and review of literature. Int. J. Dental Sci. Res. 2014, 2, 106-8, https://doi.org/10.12691/ijdsr-2-51 .

25. Silverman, S. Demographics and occurrence of oral and pharyngeal cancers. J. Am. Dent. Asso. 2001, 132, 7S-11S, https://doi.org/10.14219/jada.archive.2001.0382.

26. Bray, F.; Ferlay, J.; Soerjomataram, I.; Siegel, R.L.; Torre, L.A.; Jemal, A. Global cancer statistics 2018: GLOBOCAN estimates of incidence and mortality worldwide for 36 cancers in 185 countries. CA: Cancer J. Clin. 2018, https://doi.org/10.3322/caac.21492.

27. Joseph, B.K. Oral cancer: Prevention and detection. Med. Princ. Pract. 2002, 11, 32-5, https://doi.org/10.1159/000057776.

28. Campo-Trapero, J.; Cano-Sánchez, J.; Palacios-Sánchez, B.; Sánchez-Gutierrez, J.J.; González-Moles, M.A.; Bascones-Martínez, A. Update on molecular pathology in oral cancer and precancer. Anticancer Res. 2008, 28, 1197-205.

29. Patel, V.; Ieethanakul, C.; Gutkind, J.S. New approaches to the understanding of the molecular basis of oral cancer. Crit. Rev. Oral Biol. Med. 2001, 12, 55-63, https://doi.org/10.1177/10454411010120010401.

30. Tsantoulis, P.K.; Kastrinakis, N.G.; Tourvas, A.D.; Laskaris, G.; Gorgoulis, V.G. Advances in the biology of oral cancer. Oral Oncol. 2007, 43, 523-34, https://doi.org/10.1016/j.oraloncology.2006.11.010.

31. Viet, C.T.; Schmidt, B.L. Understanding oral cancer in the genome era. Head Neck 2010, 32, 1246-68, https://doi.org/10.1002/hed.21358.

32. Slaughter, D.P.; Southwick, H.W.; Smejkal, W. Field cancerization in oral stratified squamous epitheliumClinical implications of multicentric origin. Cancer 1953, 6, 963-8, https://doi.org/10.1002/10970142(195309)6:5<963::aid-cncr2820060515>3.0.co;2-q.

33. Willis, R.A. Further studies on the mode of origin of carcinomas of the skin. Cancer Res. 1945, 5, 469-79.

34. Boyle, J.O.; Hakim, J.; Koch, W.; van der Riet, P.; Hruban, R.H.; Roa, R.A.; Correo, R.; Eby, Y.J.; Ruppert, J.M.; Sidransky, D. The incidence of p53 mutations increases with progression of head and neck cancer. Cancer Res. 1993, 53, 4477-80.

35. Brennan, J.A.; Boyle, J.O.; Koch, W.M.; Goodman, S.N.; Hruban, R.H.; Eby, Y.J.; Couch, M.J.; Forastiere, A.A.; Sidransky, D. Association between cigarette smoking and mutation of the p53 gene in squamous-cell carcinoma of the head and neck. New Engl. J. Med. 1995, 332, 712-7, https://doi.org/10.1056/NEJM199503163321104.

36. Braakhuis, B.J.; Tabor, M.P.; Kummer, J.A.; Leemans, C.R.; Brakenhoff, R. H. A genetic explanation of Slaughter's concept of field cancerization: evidence and clinical implications. Cancer Res. 2003, 63, 172730.

37. Tanaka, T.; Tanaka, M.; Tanaka, T. Oral carcinogenesis and oral cancer chemoprevention: A review. Pathol. Res. Int. 2011, 1-10, https://doi.org/10.4061/2011/431246.

38. Upadhyay, S.K. Transmission dynamics and environmental influence on food borne parasitic helminthes of the Gangetic plains and central west coast of India. Unpubl. D.Phil. Thesis Univ. Alld. 2012, 1-400. 
39. Reshmi, S.C.; Gollin, S.M. Chromosomal instability in oral cancer cells. J. Dental Res. 2005, 84, 107-17, https://doi.org/10.1177/154405910508400203.

40. Jurel, S.K.; Gupta, D. S.; Singh, R. D.; Singh, M.; Srivastava, S. Genes and oral cancer. Indian J. Human Gen. 2014, 20, 4-9, https://doi.org/10.4103/0971-6866.132745.

41. Sidransky, D. Molecular genetics of head and neck cancer. Curr. Opin. Oncol. 1995, 7, 229-33, https://doi.org/10.1097/00001622-199505000-00007.

42. Tuli, H.S.; Bhatia, G.K.; Sood, S.; Debnath, P.; Upadhyay, S.K.; Kumar, P.; Nene, A.G.; Kumar, J.; Punia, S.; Talwar, S.; Yadav, P. In Silico evaluation of harmane \& palmarin as $\alpha$-Glucosidase inhibitors: Hope for the discovery of antihyperglycemic compounds. Int. J. Pharma. Res. 2020, 12, 1331-6, https://doi.org/10.31838/ijpr/2020.SP1.176.

43. Bishop J.M. Molecular themes in oncogenesis. Cell 1991, 64, 235-48, https://doi.org/10.1016/00928674(91)90636-d.

44. Croce, C.M. Oncogenes and cancer. New Engl. J. Med. 2008, 358, 50211, https://doi.org/10.1056/nejmra072367.

45. Field, J.K. Oncogenes and tumour-suppressor genes in squamous cell carcinoma of the head and neck. Eur. J. Cancer B Oral Oncol. 1992, 28B, 67-76, https://doi.org/10.1016/0964-1955(92)90016-t.

46. Vogelstein, B.; Kinzler, K.W. The multistep nature of cancer. Trends Gen. 1993, 9, 138-41, https://doi.org/10.1016/0168-9525(93)90209-z.

47. Renan, M.J. How many mutations are required for tumourigenesis? Implications from human cancer data. Mol. Carcinogen. 1993, 7, 139-46, https://doi.org/10.1002/mc.2940070303.

48. Bishop, J.M. Molecular themes in oncogenesis. Cell 1991, 64, 235-48, https://doi.org/10.1016/00928674(91)90636-d.

49. Tuli, H.S.; Sood, S.; Bhatia, G.K.; Debnath, P.; Aggarwal, D.; Upadhyay, S. K. In silico analysis and molecular docking studies of plumbagin and piperine ligands as potential inhibitors of alpha-glucosidase receptor. Bioint. Res. Appl. Chem. 2021, 11, 9629-37, https://doi.org/10.33263/BRIAC112.96299637.

50. Weiner, T.; Cance, W.G. Molecular mechanisms involved in tumourigenesis and their surgical implications. Am. J. Surg. 1994, 167, 428-34, https://doi.org/10.1016/0002-9610(94)90129-5.

51. Vokes, E.E.; Weichselbaum, R.R.; Lippman, S.M.; Hong, W.K. Head and neck cancer. New Engl. J. Med. 1993, 328, 184-94, https://doi.org/10.1056/NEJM199301213280306.

52. Todd, R.; Donoff, R.B.; Wong, D.T. The molecular biology of oral carcinogenesis: Toward a tumour progression model. J. Oral Max. Fac. Surg. 1997, 55, 613-23, https://doi.org/10.1016/s02782391(97)90495-x.

53. Singh, R.; Upadhyay, S.K.; Singh, M.; Sharma, I.; Sharma, P.; Kamboj, P.; Saini, A.; Voraha, R.; Sharma, A.K.; Upadhyay, T.K.; Khan, F. Chitin, chitinases and chitin derivatives in biopharmaceutical, agricultural and environmental perpective. Bioint. Res. Appl. Chem. 2021, 11, 9985-10005, https://doi.org/10.33263/BRIAC113.998510005.

54. Janet, S.B. Viral carcinogenesis: Revelation of molecular mechanisms and etiology of human disease. Carcinogenesis 2000, 21, 405-26, https://doi.org/10.1093/carcin/21.3.405.

55. Doharey, V.; Kumar, M.; Upadhyay, S.K.; Singh, R.; Kumari, B. Pharmacognostic, physicochemical and pharmaceutical paradigm of ash gourd, Benincasa hispida (Thunb.) fruit. Plant Arch. 2021, 21, 249-52, https://doi.org/10.51470/PLANTARCHIVES.2021.v21.S1.041.

56. Berenson, J.R.; Yang, J.; Mickel, R.A. Frequent amplification of the bcl-1 locus in head and neck squamous cell carcinomas. Oncogenesis 1989, 4, 1111-6.

57. Riviére, A.; Wilckens, C.; Löning, T. Expression of c-erbB2 and c-myc in squamous epithelia and squamous cell carcinomas of the head and neck and the lower female genital tract. J. Oral Pathol. Med. 1990, 19, 408-13, https://doi.org/10.1111/j.1600-0714.1990.tb00869.x.

58. Somers, K.D.; Cartwright, S.L.; Schechter, G.L. Amplification of the int-2 gene in human head and neck squamous cell carcinomas. Oncogenesis 1990, 5, 915-20.

59. Krishna, A.; Singh, S.; Kumar, V.; Pal, U.S.. Molecular concept in human oral cancer. Natl. J. Max. Fac. Surg. 2015, 6, 9-15, https://doi.org/10.4103/0975-5950.168235.

60. Bishop, J.M. Molecular themes in oncogenesis. Cell 1991, 64, 235-48, https://doi.org/10.1016/00928674(91)90636-d.

61. Aggarwal, D.; Upadhyay, S.K.; Singh, R.; Tuli, H.S. Recent patents on therapeutic activities of xanthohumol: A prenylated chalconoid from hops (Humulus lupulus L.). Pharma. Patent Analyst 2021, 10, 37-49, https://doi.org/10.4155/ppa-2020-0026.

62. Chial, H. Proto-oncogenes to oncogenes to cancer. Nat. Edu. 2008, 1, 33.

63. Saranath, D.; Panchal, R.G.; Nair, R.; Mehta, A.R.; Sanghavi, V.; Sumegi, J.; Klein, G.; Deo, M.G. Oncogene amplification in squamous cell carcinoma of the oral cavity. Jpn. J. Cancer Res. 1989, 80, 4307, https://doi.org/10.1111/j.1349-7006.1989.tb02332.x.

64. Saranath, D.; Panchal, R.G.; Nair, R.; Mehta, A.R.; Sanghavi, V.D.; Deo, M.G. Amplification and overexpression of epidermal growth factor receptor gene in human oropharyngeal cancer. Eur. J. Cancer B Oral Oncol. 1992, 28B, 139-43, https://doi.org/10.1016/0964-1955(92)90043-z. 
65. Saranath, D.; Bhoite, L.T.; Deo, M.G.; Tandle, A.T.; D'Costa, J.; Kolhapure, R.N.; Govardhan, M.K. Banerjee, K.Detection and cloning of potent transforming gene(s) from chewing tobacco-related human oral carcinomas. Eur. J. Cancer Oral Oncol. 1994, 30B, 268-77, https://doi.org/10.1016/09641955(94)90009-4.

66. Roschger, C.; Cabrele, C. The Id-protein family in developmental and cancer-associated pathways. Cell Comm. Sign. 2017, 15, 7, https://doi.org/10.1186/s12964-016-0161-y.

67. Wong, D.T.W., Todd, R., Tsuji, T., Donoff, R. B. Molecular biology of human oral cancer. Crit. Rev. Oral Biol. Med. 1996, 7, 319-28, https://doi.org/10.1177/10454411960070040201.

68. Singh, R.; Upadhyay, S.K.; Rani, A.; Kumar, P.; Sharma, P.; Sharma, I.; Singh, C.; Chauhan, N.; Kumar, M. Ethnobotanical study of weed flora at district Ambala, Haryana, India: Comprehensive medicinal and pharmacological aspects of plant resources. Int. J. Pharma. Res. 2020, 12, 1941-56, https://doi.org/10.31838/ijpr/2020.SP1.223.

69. Todd, R.; Chou, M.Y.; Matossian, K.; Gallagher, G.T.; Donoff, R.B.; Wong, D.T. Cellular sources of transforming growth factor-alpha in human oral cancer. J. Dental Res. 1991, 70, 917-23, https://doi.org/10.1177/00220345910700051101.

70. Coffey, R.J.; Jr Meise, K.S.; Matsui, Y.; Hogan, B.L.; Dempsey, P.J.; Halter, S.A. Acceleration of mammary neoplasia in transforming growth factor alpha transgenic mice by 7,12-dimethylbenzanthracene. Cancer Res. 1994, 54, 1678-83.

71. Nagaraj, N.S.; Datta, P.K. Targeting the transforming growth factor-beta signaling pathway in human cancer. Exp. Opin. Invest. Drugs 2010, 19, 77-91, https://doi.org/10.1517/13543780903382609.

72. Lokker, N.A.; Sullivan, C.M.; Hollenbach, S.J.; Israel, M.A.; Giese, N.A. Platelet-derived growth factor (PDGF) autocrine signaling regulates survival and mitogenic pathways in glioblastoma cells: evidence that the novel PDGF-C and PDGF-D ligands may play a role in the development of brain tumours. Cancer Res. 2002, 62, 3729-3735.

73. Aaronson S.A. Growth factors and cancer. Science 1991, 254, 1146-53, https://doi.org/10.1126/science.1659742.

74. Cantley, L.C.; Auger, K.R.; Carpenter, C.; Duckworth, B.; Graziani, A.; Kapeller, R.; Soltoff, S. Oncogenes and signal transduction. Cell 1991, 64, 281-302, https://doi.org/10.1016/0092-8674(91)90639-g.

75. Hunter T. Cooperation between oncogenes. Cell 1991, 64, 249-70, https://doi.org/10.1016/00928674(91)90637-e.

76. Garrett, C.R.; Eng, C. Cetuximab in the treatment of patients with colorectal cancer. Exp. Opin. Biol. Ther. 2011, 11, 937-49, https://doi.org/10.1517/14712598.2011.582464.

77. Ng, K.; Zhu, A.X. Targeting the epidermal growth factor receptor in metastatic colorectal cancer. Crit. Rev. Oncol. Hematol. 2008, 65, 8-20, https://doi.org/10.1016/j.critrevonc.2007.09.006.

78. Vecchione, L.; Jacobs, B.; Normanno, N.; Ciardiello, F.; Tejpar, S. EGFR-targeted therapy. Exp. Cell Res. 2011, 317, 2765-71, https://doi.org/10.1016/j.yexcr.2011.08.021.

79. Saranath, D.; Panchal, R.G.; Nair, R.; Mehta, A.R.; Sanghavi, V.D.; Deo, M.G. Amplification and overexpression of epidermal growth factor receptor gene in human oropharyngeal cancer. Eur. J. Cancer B Oral Oncol. 1992, 28B, 139-43, https://doi.org/10.1016/0964-1955(92)90043-z.

80. Singh, R.; Upadhyay, S.K.; Tuli, H.S.; Singh, M.; Kumar, V.; Yadav, M.; Aggarwal, D.; Kumar S. Ethnobotany and herbal medicine: Some local plants with anticancer activity. Bull. Pure Appl. Sci. Botany 2020, 39B, 57-64, https://doi.org/10.5958/2320-3196.2020.00009.9.

81. Dorsam, R.T.; Gutkind, J.S. G-protein-coupled receptors and cancer. Nat. Rev. Cancer 2007, 7, 79-94, https://doi.org/10.1038/nrc2069.

82. Gutkind, J.S. The pathways connecting G protein-coupled receptors to the nucleus through divergent mitogen-activated protein kinase cascades. J. Biol. Chem. 1998, 273, 1839-42, https://doi.org/10.1074/jbc.273.4.1839.

83. Takeda, S.; Kadowaki, S.; Haga, T.; Takaesu, H.; Mitaku, S. Identification of G protein-coupled receptor genes from the human genome sequence. Fed. Am. Soc. Exp. Biol. Lett. 2002, 520, 97-101, https://doi.org/10.1016/s0014-5793(02)02775-8.

84. Milligan, G.; Svoboda, P.; Brown, C.M. Why are there so many adrenoceptor subtypes? Biochem. Pharmacol. 1994, 48, 1059-1071, https://doi.org/10.1016/0006-2952(94)90141-4.

85. Cherezov, V.; Rosenbaum, D.M.; Hanson, M.A.; Rasmussen, S.G.; Thian, F.S.; Kobilka, T.S.; Choi, H.J.; Kuhn, P.; Weis, W.I.; Kobilka, B.K.; Stevens, R.C. High-resolution crystal structure of an engineered human beta2-adrenergic G protein-coupled receptor. Science 2007, 318, 1258-65, https://doi.org/10.1126/science.1150577.

86. Dhanasekaran, N.; Tsim, S.T.; Dermott, J.M.; Onesime, D. Regulation of cell proliferation by G proteins. Oncogen. Rev. 1998, 1383-94, https://doi.org/10.1038/sj.onc.1202242.

87. Wan, Y.; Huang, X.Y. Analysis of the Gs/mitogen-activated protein kinase pathway in mutant S49 cells. J. Biol. Chem. 1998, 273, 14533-37, https://doi.org/10.1074/jbc.273.23.14533.

88. Masur, K.; Niggemann, B.; Zanker, K.S.; Entschladen, F. Norepinephrine-induced migration of SW 480 colon carcinoma cells is inhibited by beta-blockers. Cancer Res. 2001, 61, 2866-9. 
89. Drell, T.L.; Joseph, J.; Lang, K.; Niggemann, B.; Zaenker, K.S.; Entschladen, F. Effects of neurotransmitters on the chemokinesis and chemotaxis of MDA-MB-468 human breast carcinoma cells. Breast Cancer Res. Treat. 2003, 80, 63-70, https://doi.org/10.1023/A:1024491219366.

90. Palm, D.; Lang, K.; Niggemann, B.; Drell, T.L.; Masur, K.; Zaenker, K.S.; Entschladen, F. The norepinephrine-driven metastasis development of PC-3 human prostate cancer cells in BALB/c nude mice is inhibited by beta-blockers. Int. J. Cancer 2006, 118, 2744-9, https://doi.org/10.1002/ijc.21723.

91. Adjei, A.A.; Hidalgo, M. Intracellular signal transduction pathway proteins as targets for cancer therapy. J. Clin. Oncol. 2005, 23, 5386-403, https://doi.org/10.1200/JCO.2005.23.648.

92. Yadav, M.; Sehrawat, N.; Singh, M.; Upadhyay, S.K.; Aggarwal, D.; Sharma, A.K. Cardioprotective and hepatoprotective potential of citrus flavonoid naringin: Current status and future perspectives for health benefits. Asian J. Biol. Life Sci. 2020, 9, 1-5, https://doi.org/10.5530/ajbls.2020.9.1.

93. Riviére, A.; Wilckens, C.; Löning, T. Expression of c-erbB2 and c-myc in squamous epithelia and squamous cell carcinomas of the head and neck and the lower female genital tract. J. Oral Pathol. Med. 1990, 19, 408-13, https://doi.org/10.1111/j.1600-0714.1990.tb00869.x.

94. Spandidos, D.A.; Lamothe, A.; Field, J.K. Multiple transcriptional activation of cellular oncogenes in human head and neck solid tumours. Anticancer Res. 1985, 5, 221-4.

95. Hooper, M.L. The role of the p53 and Rb-1 genes in cancer, development and apoptosis. J. Cell Sci. Suppl. 1994, 18, 13-7, https://doi.org/10.1242/jcs.1994.supplement_18.3.

96. Williams H.K. Molecular pathogenesis of oral squamous carcinoma. Mol. Pathol. 2000, 53, 165-72, https://doi.org/10.1136/mp.53.4.165.

97. Callender, T.; el-Naggar, A.K.; Lee, M.S.; Frankenthaler, R.; Luna, M.A.; Batsakis, J.G. PRAD-1 (CCND1)/ cyclin D1 oncogene amplification in primary head and neck squamous cell carcinoma. Cancer 1994, 74, 152-8, https://doi.org/10.1002/1097-0142(19940701)74:1<152::aid-cncr2820740124>3.0.co;2$\mathrm{k}$.

98. Oltvai, Z.N.; Milliman, C.L.; Korsmeyer, S.J. Bcl-2 heterodimerizes in vivo with a conserved homolog, Bax, that accelerates programmed cell death. Cell 1993, 74, 609-19, https://doi.org/10.1016/00928674(93)90509-o.

99. Korsmeyer S.J. Bcl-2 initiates a new category of oncogenes: Regulators of cell death. Blood 1992, 80, 87986.

100. Leek, R.D.; Kaklamanis, L.; Pezzella, F.; Gatter, K.C.; Harris, A.L. Bcl-2 in normal human breast and carcinoma, association with oestrogen receptor-positive, epidermal growth factor receptor-negative tumours and in situ cancer. Brit. J. cancer 1994, 69, 135-9, https://doi.org/10.1038/bjc.1994.22.

101. Pezzella, F.; Tse, A.G.; Cordell, J.L.; Pulford, K.A.; Gatter, K.C.; Mason, D.Y. Expression of the bcl-2 oncogene protein is not specific for the 14;18 chromosomal translocation. Am. J. Pathol. 1990, 137, 22532.

102. Pilotti, S.; Collini, P.; Rilke, F.; Cattoretti, G.; Del Bo, R.; Pierotti, M.A. Bcl-2 protein expression in carcinomas originating from the follicular epithelium of the thyroid gland. J. Pathol. 1994, 172, 337-42, https://doi.org/10.1002/path.1711720408.

103. Nakagawa, K.; Yamamura, K.; Maeda, S.; Ichihashi, M. bcl-2 expression in epidermal keratinocytic diseases. Cancer 1994, 74, 1720-4, https://doi.org/10.1002/1097-0142(19940915)74:6<1720::aidcncr2820740613>3.0.co;2-t.

104. Ramsay, J.A.; From, L.; Kahn, H.J. Bcl-2 protein expression in melanocytic neoplasms of the skin. Mod. Pathol. 1995, 8, 150-4.

105. Pezzella, F.; Turley, H.; Kuzu, I.; Tungekar, M.F.; Dunnill, M.S.; Pierce, C.B.; Harris, A.; Gatter, K.C.; Mason, D.Y. Bcl-2 protein in non-small-cell lung carcinoma. New Engl. J. Med. 1993, 329, 690-4, https://doi.org/10.1056/NEJM199309023291003.

106. Laudanski, J.; Chyczewski, L.; Niklińska, W.E.; Kretowska, M.; Furman, M.; Sawicki, B.; Nikliński, J. Expression of bcl-2 protein in non-small cell lung cancer: Correlation with clinicopathology and patient survival. Neoplasma 1999, 46, 25-30.

107. Castle, V.P.; Heidelberger, K.P.; Bromberg, J.; Ou, X.; Dole, M.; Nuñez, G. Expression of the apoptosissuppressing protein bcl-2, in neuroblastoma is associated with unfavorable histology and N-myc amplification. Am. J. Pathol. 1993, 143, 1543-50.

108. Jordan, R.C.K.; Catzavelos, G.C.; Barrett, A.W.; Speight, P.M. Differential expression of bcl-2 and bax in squamous cell carcinomas of the oral cavity. Eur. J. Cancer Oral Oncol. 1996, 32, 394-400, https://doi.org/10.1016/s0964-1955(96)00033-4.

109. McCall, C.A.; Cohen, J.J. Programmed cell death in terminally differentiating keratinocytes: Role of endogenous endonuclease. J. Inv. Dermatol. 1991,97, 111-4, https://doi.org/10.1111/15231747.ep12478519.

110. Lumerman, H.; Freedman, P.; Kerpel, S. Oral epithelial dysplasia and the development of invasive squamous cell carcinoma. Oral Surg. Med. Pathol. Radiol. Endo. 1995, 79, 321-9, https://doi.org/10.1016/s1079-2104(05)80226-4.

111. Yadav, D.; Upadhyay, S.K.; Anwar, M.F.; Unnithan, J.S. A review on the patents of various metal nanoparticles: preparations and formulations. World J. Pharm. Pharma. Sci. 2016, 5, 1309-17. 
112. Ogden, G.R.; Kiddie, R.A.; Lunny, D.P.; Lane, D.P. Assessment of p53 protein expression in normal, benign, and malignant oral mucosa. J. Pathol. 1992, 166, 389-94, https://doi.org/10.1002/path.1711660411.

113. Huang, W.Y.; Coltrera, M.; Schubert, M.; Morton, T.; Truelove, E. Histopathologic evaluation of proliferating cell nuclear antigen (PC10) in oral epithelial hyperplasias and premalignant lesions. Oral Surg. Med. Pathol. 1994, 78, 748-54, https://doi.org/10.1016/0030-4220(94)90091-4.

114. Bronner, M.P.; Culin, C.; Reed, J.C.; Furth, E.E. The bcl-2 proto-oncogene and the gastrointestinal epithelial tumour progression model. Am. J. Pathol. 1995, 146, 20-6.

115. Lauwers, G.Y.; Scott, G.V.; Hendricks, J. Immunohistochemical evidence of aberrant bcl-2 protein expression in gastric epithelial dysplasia. Cancer 1994, 73, 2900-04, https://doi.org/10.1002/10970142(19940615)73:12<2900::aid-cncr2820731205>3.0.co;2-0.

116. Elmore, S. Apoptosis: A review of programmed cell death. Toxicol. Pathol. 2007, 35, 495516, https://doi.org/10.1080/01926230701320337.

117. Evans, T.; Rosenthal, E.T.; Youngblom, J.; Distel, D.; Hunt, T. Cyclin: A protein specified by maternal mRNA in sea urchin eggs that is destroyed at each cleavage division. Cell 1983, 33, 389-96, https://doi.org/10.1016/0092-8674(83)90420-8.

118. Goodger, N.; Gannon, J.; Hunt, T.; Morgan, P. Cell cycle regulatory proteins- An overview with relevance to oral cancer. Oral Oncol. 1997, 33, 61-73, https://doi.org/10.1016/s0964-1955(96)00071-1.

119. Lew, D.J.; Dulić, V.; Reed, S.I. Isolation of three novel human cyclins by rescue of G1 cyclin (Cln) function in yeast. Cell 1991, 66, 1197-206, https://doi.org/10.1016/0092-8674(91)90042-w.

120. Kobayashi, H.; Stewart, E.; Poon, R.; Adamczewski, J.P.; Gannon, J.; Hunt, T. Identification of the domains in cyclin-A required for binding to, and activation of, p34cdc2 and p32cdk2 protein kinase subunits. Mol. Biol. Cell 1992, 3, 1279-94, https://doi.org/10.1091/mbc.3.11.1279.

121. Lees, E.M.; Harlow, E. Sequences within the conserved cyclin box of human cyclin A are sufficient for binding to and activation of cdc2 kinase. Mol. Cell. Biol. 1993, 13, 1194-1201, https://doi.org/10.1128/mcb.13.2.1194.

122. Jeffrey, P.D.; Russo, A.A.; Polyak, K.; Gibbs, E.; Hurwitz, J.; Massagué, J.; Pavletich, N.P. Mechanism of CDK activation revealed by the structure of a cyclinA-CDK2 complex. Nature 1995, 376, 313-20, https://doi.org/10.1038/376313a0.

123. Glotzer, M.; Murray, A.W.; Kirschner, M.W. Cyclin is degraded by the ubiquitin pathway. Nature 1991, 349, 132-8, https://doi.org/10.1038/349132a0.

124. Girard, F.; Strausfeld, U.; Fernandez, A.; Lamb, N.J. Cyclin A is required for the onset of DNA replication in mammalian fibroblasts. Cell 1991, 67, 1169-79. https://doi.org/10.1016/0092-8674(91)90293-8.

125. Henglein, B.; Chenivesse, X.; Wang, J.; Eick, D.; Bréchot, C. Structure and cell cycle-regulated transcription of the human cyclin A gene. Proc. Natl. Acad. Sci. U.S.A. 1994, 91, 5490-4, https://doi.org/10.1073/pnas.91.12.5490.

126. Roberts J.M. Turning DNA replication on and off. Curr. Opin. Cell Biol. 1993, 5, 201-6, https://doi.org/10.1016/0955-0674(93)90103-w.

127. Maity, A.; McKenna, W.G.; Muschel, R.J. Evidence for post-transcriptional regulation of cyclin B1 mRNA in the cell cycle and following irradiation in HeLa cells. EMBO J. 1995, 14, 603-9.

128. Pines, J.; Hunter, T. Human cell division: The involvement of cyclins A and B1, and multiple cdc2s. Cold Spring Harbor Symp. Quant. Biol. 1991, 56, 449-63, https://doi.org/10.1101/sqb.1991.056.01.052.

129. Pines, J.; Hunter, T. Human cyclins A and B1 are differentially located in the cell and undergo cell cycledependent nuclear transport. J. Cell Biol. 1991, 115, 1-17, https://doi.org/10.1083/jcb.115.1.1.

130. Holloway, S.L.; Glotzer, M.; King, R.W.; Murray, A.W. Anaphase is initiated by proteolysis rather than by the inactivation of maturation-promoting factor. Cell 1993, 73, 1393-1402, https://doi.org/10.1016/0092-8674(93)90364-v.

131. Léopold, P.; O'Farrell, P.H. An evolutionarily conserved cyclin homolog from Drosophila rescues yeast deficient in G1 cyclins. Cell 1991, 66, 1207-1216, https://doi.org/10.1016/0092-8674(91)90043-x.

132. Singh, R.; Upadhyay, S.K.; Rani, A.; Kumar, P.; Kumar, A. Ethanobotanical study of Subhartipuram, Meerut, Uttar Pradesh, India. II. Diversity and pharmacological significance of shrubs and climbers. Int. J. Pharma. Res. 2020, 12, 383-93, https://doi.org/10.31838/ijpr/2020.12.02.0050.

133. Geng, Y.; Weinberg, R.A. Transforming growth factor beta effects on expression of G1 cyclins and cyclindependent protein kinases. Proc. Natl. Acad. Sci. U.S.A. 1993, 90, 10315-9, https://doi.org/10.1073/pnas.90.21.10315.

134. Draetta G.F. Mammalian G1 cyclins. Curr. Opin. Cell Biol. 1994, 6, 842-6, https://doi.org/10.1016/09550674(94)90054-X.

135. Xiong, Y.; Connolly, T.; Futcher, B.; Beach, D. Human D-type cyclin. Cell 1991, 65, 691-9, https://doi.org/10.1016/0092-8674(91)90100-d.

136. Xiong, Y.; Menninger, J.; Beach, D.; Ward, D.C. Molecular cloning and chromosomal mapping of CCND genes encoding human D-type cyclins. Genomics 1992, 13, 575-84, https://doi.org/10.1016/08887543(92)90127-e. 
137. Inaba, T.; Matsushime, H.; Valentine, M.; Roussel, M.F.; Sherr, C.J.; Look, A.T. Genomic organization, chromosomal localization, and independent expression of human cyclin D genes. Genomics 1992, 13, 56574, https://doi.org/10.1016/0888-7543(92)90126-d.

138. Baldin, V.; Lukas, J.; Marcote, M.J.; Pagano, M.; Draetta, G. Cyclin D1 is a nuclear protein required for cell cycle progression in G1. Genes Develop. 1993, 7, 812-21, https://doi.org/10.1101/gad.7.5.812.

139. Skapek, S.X.; Rhee, J.; Spicer, D.B.; Lassar, A.B. Inhibition of myogenic differentiation in proliferating myoblasts by cyclin D1-dependent kinase. Science 1995, 267, 1022-4, https://doi.org/10.1126/science.7863328.

140. Koff, A.; Giordano, A.; Desai, D.; Yamashita, K.; Harper, J.W.; Elledge, S.; Nishimoto, T.; Morgan, D.O.; Franza, B.R.; Roberts, J.M. Formation and activation of a cyclin E-cdk2 complex during the G1 phase of the human cell cycle. Science 1992, 257, 1689-94, https://doi.org/10.1126/science.1388288.

141. Okamoto, K.; Beach, D. Cyclin G is a transcriptional target of the p53 tumour suppressor protein. EMBO J. 1994, 13, 4816-22.

142. Fisher, R.P.; Morgan, D.O. A novel cyclin associates with MO15/CDK7 to form the CDK-activating kinase. Cell 1994, 78, 713-24, https://doi.org/10.1016/0092-8674(94)90535-5.

143. Meyerson, M.; Faha, B.; Su, L.K.; Harlow, E.; Tsai, L.H. The cyclin-dependent kinase family. Cold Spring Harbor Symp. Quant. Biol. 1991, 56, 177-86, https://doi.org/10.1101/sqb.1991.056.01.023.

144. Lee, M.G.; Nurse, P. Complementation used to clone a human homologue of the fission yeast cell cycle control gene cdc2. Nature, 1987, 327, 31-5, https://doi.org/10.1038/327031a0.

145. Draetta, G.; Brizuela, L.; Potashkin, J.; Beach, D. Identification of p34 and p13, human homologs of the cell cycle regulators of fission yeast encoded by cdc2+ and suc1+. Cell, 1987, 50, 319-25, https://doi.org/10.1016/0092-8674(87)90227-3.

146. Meyerson, M.; Enders, G.H.; Wu, C.L.; Su, L.K.; Gorka, C.; Nelson, C.; Harlow, E.; Tsai, L.H. A family of human cdc2-related protein kinases. EMBO J. 1992, 11, 2909-17.

147. Bates, S.; Bonetta, L.; MacAllan, D.; Parry, D.; Holder, A.; Dickson, C.; Peters, G. CDK6 (PLSTIRE) and CDK4 (PSK-J3) are a distinct subset of the cyclin-dependent kinases that associate with cyclin D1. Oncogene 1994, 9, 71-9.

148. Tassan, J.P.; Jaquenoud, M.; Léopold, P.; Schultz, S.J.; Nigg, E.A. Identification of human cyclindependent kinase 8, a putative protein kinase partner for cyclin C. Proc. Natl. Acad. Sci. U.S.A. 1995, 92, 8871-5, https://doi.org/10.1073/pnas.92.19.8871.

149. Elledge, S.J.; Richman, R.; Hall, F.L.; Williams, R.T.; Lodgson, N.; Harper, J.W. CDK2 encodes a 33-kDa cyclin A-associated protein kinase and is expressed before CDC2 in the cell cycle. Proc. Natl. Acad. Sci. U.S.A. 1992, 89, 2907-11, https://doi.org/10.1073/pnas.89.7.2907.

150. Draetta, G.; Beach, D. Activation of cdc2 protein kinase during mitosis in human cells: Cell cycledependent phosphorylation and subunit rearrangement. Cell 1988, 54, 17-26, https://doi.org/10.1016/0092-8674(88)90175-4.

151. Draetta, G.; Luca, F.; Westendorf, J.; Brizuela, L.; Ruderman, J.; Beach, D. Cdc2 protein kinase is complexed with both cyclin A and B: evidence for proteolytic inactivation of MPF. Cell 1989, 56, 829-38, https://doi.org/10.1016/0092-8674(89)90687-9.

152. Gautier, J.; Minshull, J.; Lohka, M.; Glotzer, M.; Hunt, T.; Maller, J.L. Cyclin is a component of maturation-promoting factor from Xenopus. Cell 1990,60, 487-94, https://doi.org/10.1016/00928674(90)90599-a.

153. Labbé, J.C.; Capony, J.P.; Caput, D.; Cavadore, J.C.; Derancourt, J.; Kaghad, M.; Lelias, J.M.; Picard, A.; Dorée, M. MPF from starfish oocytes at first meiotic metaphase is a heterodimer containing one molecule of cdc2 and one molecule of cyclin B. EMBO J. 1989, 8, 3053-8.

154. Welch, P.J.; Wang, J.Y. Coordinated synthesis and degradation of cdc2 in the mammalian cell cycle. Proc. Natl. Acad. Sci. U.S.A. 1992, 89, 3093-7, https://doi.org/10.1073/pnas.89.7.3093.

155. Meyerson, M.; Harlow, E. Identification of G1 kinase activity for cdk6, a novel cyclin D partner. Mol. Cell. Biol. 1994, 14, 2077-86, https://doi.org/10.1128/mcb.14.3.2077.

156. Koff, A.; Cross, F.; Fisher, A.; Schumacher, J.; Leguellec, K.; Philippe, M.; Roberts, J. M. Human cyclin $\mathrm{E}$, a new cyclin that interacts with two members of the CDC2 gene family. Cell 1991, 66, 1217-28, https://doi.org/10.1016/0092-8674(91)90044-y.

157. Solomon, M.J.; Harper, J.W.; Shuttleworth, J. CAK, the p34cdc2 activating kinase, contains a protein identical or closely related to p40MO15. EMBO J. 1993, 12(8), 3133-42.

158. Tassan, J.P.; Jaquenoud, M.; Fry, A.M.; Frutiger, S.; Hughes, G.J.; Nigg, E.A. In vitro assembly of a functional human CDK7-cyclin $\mathrm{H}$ complex requires MAT1, a novel $36 \mathrm{kDa}$ RING finger protein. EMBO J. 1995, 14, 5608-17.

159. Tsai, L. H.; Takahashi, T.; Caviness, V.S.; Jr, Harlow, E. Activity and expression pattern of cyclindependent kinase 5 in the embryonic mouse nervous system. Development 1993, 119, 1029-40.

160. Xiong, Y.; Zhang, H.; Beach, D. D type cyclins associate with multiple protein kinases and the DNA replication and repair factor PCNA. Cell 1992, 71, 505-14, https://doi.org/10.1016/0092-8674(92)90518h. 
161. Singh, M.; Renu; Kumar V.; Upadhyay, S.K.; Singh R.; Yadav, M.; Seema; Kumari, S.; Sharma, A.K.; Manikandan, S. Biomimetic synthesis of silver nanoparticle from aqueous extract of Saraca indica and its profound antibacterial activity. Bioint. Res. Appl. Chem. 2021, 11, 8110-20, https://doi.org/10.33263/BRIAC111.81108120.

162. Rosenblatt, J.; Gu, Y.; Morgan, D.O. Human cyclin-dependent kinase 2 is activated during the S and G2 phases of the cell cycle and associates with cyclin A. Proc. Natl. Acad. Sci. U.S.A. 1992, 89, 2824-8, https://doi.org/10.1073/pnas.89.7.2824.

163. Upadhyay, S.K.; Dan, S.; Girdhar, M.; Rastogi, K. Recent advancement in SARS-CoV-2 diagnosis, treatment and vaccine formulation: A new paradigm of nanotechnology in strategic combating of COVID19 pandemic. Curr. Pharmacol. Rep. 2021, 7, 1-14, https://doi.org/10.1007/s40495-021-00250-z.

164. Dorée, M.; Galas, S. The cyclin-dependent protein kinases and the control of cell division. Fed. Am. Soc. Exp. Biol. J. 1994, 8, 1114-21, https://doi.org/10.1096/fasebj.8.14.7958616.

165. Lees, E.; Faha, B.; Dulic, V.; Reed, S.I.; Harlow, E. Cyclin E/cdk2 and cyclin A/cdk2 kinases associate with p107 and E2F in a temporally distinct manner. Genes Develop. 1992, 6, 1874-85, https://doi.org/10.1101/gad.6.10.1874.

166. Sardet, C.; Vidal, M.; Cobrinik, D.; Geng, Y.; Onufryk, C.; Chen, A.; Weinberg, R.A. E2F-4 and E2F-5, two members of the E2F family, are expressed in the early phases of the cell cycle. Proc. Natl. Acad. Sci. U.S.A. 1995, 92, 2403-7, https://doi.org/10.1073/pnas.92.6.2403.

167. Singh, M.; Renu; Kamboj, S.; Kumari, S.; Kamboj, V.; Upadhyay, S.K. One pot synthesis of physicochemically stabilized $\mathrm{ZnO}$ nanoparticles via biological method and its potential application as antimicrobial agent. Bull. Pure Appl.Sci. Zool. 2020, 39A, 116-129, https://doi.org/10.5958/2320-3188.2020.00014.5.

168. Field, S.J.; Tsai, F.Y.; Kuo, F.; Zubiaga, A.M.; Kaelin, W.G.; Jr, Livingston, D.M.; Orkin, S.H.; Greenberg, M.E. E2F-1 functions in mice to promote apoptosis and suppress proliferation. Cell 1996, 85, 549-61, https://doi.org/10.1016/s0092-8674(00)81255-6.

169. Pennisi, R.; Ascenzi, P.; di Masi, A. Hsp90: A new player in DNA repair? Biomolecules 2015, 5, 2589618, https://doi.org/10.3390/biom5042589.

170. Browner, W.S.; Kahn, A.J.; Ziv, E.; Reiner, A.P.; Oshima, J.; Cawthon, R.M.; Hsueh, W.C.; Cummings, S.R. The genetics of human longevity. Am. J. Med. 2004,117, 851-60, https://doi.org/10.1016/j.amjmed.2004.06.033.

171. Scully, C.; Field, J.K.; Tanzawa, H. Genetic aberrations in oral or head and neck squamous cell carcinoma (SCCHN): 1. Carcinogen metabolism, DNA repair and cell cycle control. Oral Oncol. 2000, 36, 256-63, https://doi.org/10.1016/s1368-8375(00)00007-5.

172. Lindahl, T.; Prigent, C.; Barnes, D.E.; Lehmann, A.R.; Satoh, M.S.; Roberts, E.; Nash, R. A.; Robins, P.; Daly, G. DNA joining in mammalian cells. Cold Spring Harbor Symp. Quant. Biol. 1993, 58, 619-24, https://doi.org/10.1101/sqb.1993.058.01.068.

173. Kim, Y.J.; Wilson, D.M. Overview of base excision repair biochemistry. Curr. Mol. Pharmacol. 2012, 5, 3-13, https://doi.org/10.2174/1874467211205010003.

174. Reardon, J.T.; Sancar, A. Purification and characterization of Escherichia coli and human nucleotide excision repair enzyme systems. Methods Enzymol. 2006, 408, 189-213, https://doi.org/10.1016/S00766879(06)08012-8.

175. Tham, K.C.; Kanaar, R.; Lebbink, J. Mismatch repair and homeologous recombination. DNA Rep. 2016, 38, 75-83, https://doi.org/10.1016/j.dnarep.2015.11.010.

176. Hsieh, P.; Yamane, K. DNA mismatch repair: Molecular mechanism, cancer, and ageing. Mech. Age. Develop. 2008, 129, 391-407, https://doi.org/10.1016/j.mad.2008.02.012.

177. Plotz, G.; Piiper, A.; Wormek, M.; Zeuzem, S.; Raedle, J. Analysis of the human MutLalpha.MutSalpha complex. Biochem. Biophys. Res. Comm. 2006, 340, 852-9, https://doi.org/10.1016/j.bbrc.2005.12.096.

178. Dynan, W.S.; Yoo, S. Interaction of Ku protein and DNA-dependent protein kinase catalytic subunit with nucleic acids. Nucleic Acids Res. 1998, 26, 1551-9, https://doi.org/10.1093/nar/26.7.1551.

179. Lieber M.R. The mechanism of double-strand DNA break repair by the nonhomologous DNA end-joining $\begin{array}{llll}\text { pathway. Ann. } & \text { Rev. Biochem. }\end{array}$ https://doi.org/10.1146/annurev.biochem.052308.093131.

180. Goodarzi, A.A.; Jeggo, P. A. The repair and signaling responses to DNA double-strand breaks. Adv. Gen. 2013, 82, 1-45, https://doi.org/10.1016/B978-0-12-407676-1.00001-9.

181. di Masi, A.; Gullotta, F.; Cappadonna, V.; Leboffe, L.; Ascenzi, P. Cancer predisposing mutations in BRCT domains. Int. Uni. Biochem. Mol. Biol. Life 2011, 63, 503-12, https://doi.org/10.1002/iub.472.

182. Yokota, J.; Sugimura, T. Multiple steps in carcinogenesis involving alterations of multiple tumor suppressor genes. Fed. Am. Soc. Exp. Biol. J. 1993, 7, 920-25, https://doi.org/10.1096/fasebj.7.10.8344488.

183. Hollstein, M.; Sidransky, D.; Vogelstein, B.; Harris, C.C. p53 mutations in human cancers. Science, 1991, 253 49-53, https://doi.org/10.1126/science.1905840.

184. Harper, J.W.; Adami, G.R.; Wei, N.; Keyomarsi, K.; Elledge, S.J. The p21 Cdk-interacting protein Cip1 is a potent inhibitor of G1 cyclin-dependent kinases. Cell 1993, 75, 805-16, https://doi.org/10.1016/00928674(93)90499-g. 
185. el-Deiry, W.S.; Tokino, T.; Velculescu, V.E.; Levy, D.B.; Parsons, R.; Trent, J.M.; Lin, D.; Mercer, W.E.; Kinzler, K.W.; Vogelstein, B. WAF1, a potential mediator of p53 tumour suppression. Cell 1993, 75, 81725, https://doi.org/10.1016/0092-8674(93)90500-p.

186. Brennan, J.A.; Boyle, J.O.; Koch, W.M.; Goodman, S.N.; Hruban, R.H.; Eby, Y.J.; Couch, M.J.; Forastiere, A.A.; Sidransky, D. Association between cigarette smoking and mutation of the p53 gene in squamous-cell carcinoma of the head and neck. New Engl. J. Med. 1995, 332, 712-17, https://doi.org/10.1056/NEJM199503163321104.

187. Todd, R.; McBride, J.; Tsuji, T.; Donoff, R.B.; Nagai, M.; Chou, M.Y.; Chiang, T.; Wong, D.T. Deleted in oral cancer-1 (doc-1), a novel oral tumour suppressor gene. Fed. Am. Soc. Exp. Biol. J. 1995, 9, 136270, https://doi.org/10.1096/fasebj.9.13.7557027.

188. Slee, E.A.; Harte, M.T.; Kluck, R.M.; Wolf, B.B.; Casiano, C.A.; Newmeyer, D.D.; Wang, H.G.; Reed, J.C.; Nicholson, D.W.; Alnemri, E.S.; Green, D.R.; Martin, S.J. Ordering the cytochrome c-initiated caspase cascade: hierarchical activation of caspases-2, -3, -6, -7, -8, and -10 in a caspase-9-dependent manner. J. Cell Biol. 1999, 144, 281-92, https://doi.org/10.1083/jcb.144.2.281.

189. Vogelstein, B.; Lane, D.; Levine, A.J. Surfing the p53 network. Nature 2000, 408, 307-10, https://doi.org/10.1038/35042675.

190. Sax, J.K.; El-Deiry, W.S. p53 downstream targets and chemosensitivity. Cell Death Diff. 2003, 10, 413-7, https://doi.org/10.1038/sj.cdd.4401227.

191. Chipuk, J.E.; Maurer, U.; Green, D.R.; Schuler, M. Pharmacologic activation of p53 elicits Bax-dependent apoptosis in the absence of transcription. Cancer Cell 2003, 4, 371-81, https://doi.org/10.1016/s15356108(03)00272-1.

192. Marsden, V.S.; O'Connor, L.; O'Reilly, L.A.; Silke, J.; Metcalf, D.; Ekert, P.G.; Huang, D.C.; Cecconi, F.; Kuida, K.; Tomaselli, K.J.; Roy, S.; Nicholson, D.W.; Vaux, D.L.; Bouillet, P.; Adams, J.M.; Strasser, A. Apoptosis initiated by Bcl-2-regulated caspase activation independently of the cytochrome c/Apaf1/caspase-9 apoptosome. Nature 2002, 419, 634-7, https://doi.org/10.1038/nature01101.

193. Ko, L.J.; Prives, C. p53: puzzle and paradigm. Genes Develop. 1996, 10, 1054-72, https://doi.org/10.1101/gad.10.9.1054.

194. Levine A.J. p53, the cellular gatekeeper for growth and division. Cell 1997, 88, 323-31, https://doi.org/10.1016/s0092-8674(00)81871-1.

195. Rivlin, N.; Brosh, R.; Oren, M.; Rotter, V. Mutations in the p53 tumour suppressor gene: Important milestones at the various steps of tumourigenesis. Genes Cancer 2011, 2, 466-74, https://doi.org/10.1177/1947601911408889.

196. Donehower, L.A.; Harvey, M.; Slagle, B.L.; McArthur, M.J.; Montgomery, C.A.; Jr, Butel, J.S.; Bradley, A. Mice deficient for p53 are developmentally normal but susceptible to spontaneous tumours. Nature, 1992, 356, 215-21, https://doi.org/10.1038/356215a0.

197. Attardi, L.D.; Jacks, T. The role of p53 in tumour suppression: Lessons from mouse models. Cell. Mol. Life Sci. 1999, 55, 48-63, https://doi.org/10.1007/s000180050269.

198. Lang, G.A.; Iwakuma, T.; Suh, Y.A.; Liu, G.; Rao, V.A.; Parant, J.M.; Valentin-Vega, Y.A.; Terzian, T.; Caldwell, L.C.; Strong, L.C.; El-Naggar, A.K.; Lozano, G. Gain of function of a p53 hot spot mutation in a mouse model of Li-Fraumeni syndrome. Cell 2004, 119, 861-72, https://doi.org/10.1016/j.cell.2004.11.006.

199. Heinlein, C.; Krepulat, F.; Löhler, J.; Speidel, D.; Deppert, W.; Tolstonog, G.V. Mutant p53(R270H) gain of function phenotype in a mouse model for oncogene-induced mammary carcinogenesis. Int. J. Cancer 2008, 122, 1701-9, https://doi.org/10.1002/ijc.23317.

200. Muller, P.A.; Caswell, P.T.; Doyle, B.; Iwanicki, M.P.; Tan, E.H.; Karim, S.; Lukashchuk, N.; Gillespie, D.A.; Ludwig, R.L.; Gosselin, P.; Cromer, A.; Brugge, J.S.; Sansom, O.J.; Norman, J.C.; Vousden, K.H. Mutant p53 drives invasion by promoting integrin recycling. Cell 2009, 139, 1327-41, https://doi.org/10.1016/j.cell.2009.11.026.

201. Adorno, M.; Cordenonsi, M.; Montagner, M.; Dupont, S.; Wong, C.; Hann, B.; Solari, A.; Bobisse, S.; Rondina, M.B.; Guzzardo, V.; Parenti, A.R.; Rosato, A.; Bicciato, S.; Balmain, A.; Piccolo, S. A Mutantp53/Smad complex opposes p63 to empower TGFbeta-induced metastasis. Cell 2009, 137, 87-98, https://doi.org/10.1016/j.cell.2009.01.039.

202. Wang, S.P.; Wang, W.L.; Chang, Y.L.; Wu, C.T.; Chao, Y.C.; Kao, S.H.; Yuan, A.; Lin, C.W.; Yang, S.C.; Chan, W.K.; Li, K.C.; Hong, T.M.; Yang, P.C. p53 controls cancer cell invasion by inducing the MDM2mediated degradation of Slug. Nat. Cell Biol. 2009, 11, 694-704, https://doi.org/10.1038/ncb1875.

203. Chang, C.J.; Chao, C.H.; Xia, W.; Yang, J.Y.; Xiong, Y.; Li, C.W.; Yu, W.H.; Rehman, S.K.; Hsu, J.L.; Lee, H.H.; Liu, M.; Chen, C.-T.; Yu, D.; Hung, M.-C. p53 regulates epithelial-mesenchymal transition and stem cell properties through modulating miRNAs. Nature Cell Biol. 2011, 13, 317-23, https://doi.org/10.1038/ncb2173.

204. Kogan-Sakin, I.; Tabach, Y.; Buganim, Y.; Molchadsky, A.; Solomon, H.; Madar, S.; Kamer, I.; Stambolsky, P.; Shelly, A.; Goldfinger, N.; Valsesia-Wittmann, S.; Puisieux, A.; Zundelevich, A.; GalYam, E.N.; Avivi, C.; Barshack, I.; Brait, M.; Sidransky, D.; Domany, E.; Rotter, V. Mutant p53(R175H) 
upregulates Twist1 expression and promotes epithelial-mesenchymal transition in immortalized prostate cells. Cell Death Diff. 2011, 18, 271-81, https://doi.org/10.1038/cdd.2010.94.

205. Muller, P.A.; Vousden, K.H.; Norman, J.C. p53 and its mutants in tumour cell migration and invasion. $J$. Cell Biol. 2011, 192, 209-18, https://doi.org/10.1083/jcb.201009059.

206. Bossi, G.; Marampon, F.; Maor-Aloni, R.; Zani, B.; Rotter, V.; Oren.; Strano, S.; Blandino, G.; Sacchi, A. Conditional RNA interference in vivo to study mutant p53 oncogenic gain of function on tumour malignancy. Cell Cycle 2008, 7, 1870-9, https://doi.org/10.4161/cc.7.12.6161.

207. Milyavsky, M.; Tabach, Y.; Shats, I.; Erez, N.; Cohen, Y.; Tang, X.; Kalis, M.; Kogan, I.; Buganim, Y.; Goldfinger, N.; Ginsberg, D.; Harris, C.C.; Domany, E.; Rotter, V. Transcriptional programs following genetic alterations in p53, INK4A, and H-Ras genes along defined stages of malignant transformation. Cancer Res. 2005, 65, 4530-43, https://doi.org/10.1158/0008-5472.CAN-04-3880.

208. Tabach, Y.; Milyavsky, M.; Shats, I.; Brosh, R.; Zuk, O.; Yitzhaky, A.; Mantovani, R.; Domany, E.; Rotter, V.; Pilpel, Y. The promoters of human cell cycle genes integrate signals from two tumour suppressive pathways during cellular transformation. Mol. Syst. Biol. 2005, 1, 2005-22, https://doi.org/10.1038/msb4100030.

209. Brosh, R.; Shalgi, R.; Liran, A.; Landan, G.; Korotayev, K.; Nguyen, G.H.; Enerly, E.; Johnsen, H.; Buganim, Y.; Solomon, H.; Goldstein, I.; Madar, S.; Goldfinger, N.; Borresen-Dale, A.-L.; Ginsberg, D.; Harris, C.C.; Pipel, Y.; Oren, M.; Rotter, V. p53-Repressed miRNAs are involved with E2F in a feedforward loop promoting proliferation. Mol. Syst. Biol. 2008, 4, 229, https://doi.org/10.1038/msb.2008.65.

210. Buganim, Y.; Solomon, H.; Rais, Y.; Kistner, D.; Nachmany, I.; Brait, M.; Madar, S.; Goldstein, I.; Kalo, E.; Adam, N.; Gordin, M.; Rivilin, N.; Kogan, I.; Brosh, R.; Sefadia-Elad, G.; Goldfinger, N.; Sidransky, D.; Kloog, Y.; Rotter, V. p53 regulates the ras circuit to inhibit the expression of a cancer-related gene signature by various molecular pathways. Cancer Res. 2010, 70, 2274-84, https://doi.org/10.1158/00085472.CAN-09-2661.

211. Solomon, H.; Brosh, R.; Buganim, Y.; Rotter, V. Inactivation of the p53 tumour suppressor gene and activation of the Ras oncogene: Cooperative events in tumourigenesis. Dis. Med. 2010, 9, 448-54.

212. Shaloo; Vaishali; Sakshi; Dan, S. Graphene and its composites used in research of dental and oral infection. Int. J. Scient. Res. Chem. Sci. 2020, 7, 20-34.

213. Pachauri, N.; Dave, K.; Dinda, A.; Solanki, P.R. Cubic CeO2 planted reduced graphene oxide based highly sensitive biosensor for noninvasive oral cancer biomarker. J. Mater. Chem. 2016, 4, 1-178, https://doi.org/10.1039/C8TB00653A.

214. Fiorillo, M.; Verre, A.F.; Iliut, M.; Peiris-Pagés, M.; Ozsvari, B.; Gandara, R.; Capello, A.R.; Sotgia, F.; Vijayaraghavan, A.; Lisanti, M.P. Graphene oxide selectively targets cancer stem cells, across multiple tumour types: implications for non-toxic cancer treatment, via differentiation-based nano-therapy. Oncotarget 2015, 28, 3553-62, https://doi.org/10.18632/oncotarget.3348.

215. Kumar, S.; Sharma, J.G.; Maji, S.; Malhotra, B.D. Nanostructured zirconia decorated reduced graphene oxide based efficient biosensing platform for non-invasive oral cancer detection. Biosens. Bioelectron. 2016, 78, 497-504, https://doi.org/10.1016/j.bios.2015.11.084.

216. Lee, J.H.; Sahu, A.; Jang, C.; Tae, G. The effect of ligand density on in vivo tumor targeting of nanographene oxide. J. Control. Rel. 2015, 209, 219-28, https://doi.org/10.1016/j.jconrel.2015.04.035.

217. Wei, Z.; Yin, X.; Cai, Y.; Xu, W.; Song, C.; Wang, Y.; Zhang, J.; Kang, A.; Wang, Z.; Han, W. Antitumor effect of a Pt-loaded nanocomposite based on graphene quantum dots combats hypoxia-induced chemoresistance of oral squamous cell carcinoma. Int. J. Nanomed. 2018, 13, 1505-24, https://doi.org/10.2147/IJN.S156984.

218. Hou, L.; Shi, Y.; Jiang, G.; Liu, W.; Han, H.; Feng, Q.; Ren, J.; Yuan, Y.; Wang, Y.; Shi, J.; Zhang, Z. Smart nanocomposite hydrogels based on azo crosslinked graphene oxide for oral colon-specific drug delivery. Nanotechnology, 2016, 27, 315105, https://doi.org/10.1088/0957-4484/27/31/315105.

219. Zitsch, R.P.; Todd, D.W.; Renner, G.J.; Singh, A. Intraoperative radiolymphoscintigraphy for detection of occult nodal metastasis in patients with head and neck squamous cell carcinoma. Otolaryngol Head Neck Surg. 2000, 122, 662-6, https://doi.org/10.1016/S0194-5998(00)70192-6.

220. Forastiere, A.; Koch, W.; Trotti, A.; Sidransky, D. Head and neck cancer. New Engl. J. Med. 2001, 345, 1890-1900, https://doi.org/10.1056/NEJMra001375.

221. Upadhyay, S.K.; Dan, S.; Pant, M.; Shaloo. Synergistic approach of graphene oxide-silver-titanium nanocomposite film in oral and dental studies: A new paradigm of infection control in dentistry. Bioint. Res. Appl.Chem. 2021, 11, 9680-9703, https://doi.org/10.33263/BRIAC112.96809703.

222. Day, T.A.; Davis, B.K.; Gillespie, M.B.; Joe, J.K.; Kibbey, M.; Martin-Harris, B.; Neville, B.; Reed, S.G.; Richardson, M.S.; Rosenzweig, S.; Sharma, A.K.; Smith, M.M.; Stewart, S.; Stuart, R.K. Oral cancer treatment. Curr. Treat. Opt. Oncol. 2003, 4, 27-41, https://doi.org/10.1007/s11864-003-0029-4.

223. Clayman, G.L.; el-Naggar, A.K.; Lippman, S.M.; Henderson, Y.C.; Frederick, M.; Merrit, J.A.; Zumstein, L.A.; Timmons, T.M.; Liu, T.J.; Ginsberg, L.; Roth, J.A.; Hong, W.K.; Bruso, P.; Goepfert, H. Adenovirusmediated p53 gene transfer in patients with advanced recurrent head and neck squamous cell carcinoma. $J$. Clin. Oncol. 1998, 16, 2221-32, https://doi.org/10.1200/JCO.1998.16.6.2221. 
224. Singh, R.; Upadhyay, S.K.; Rani A.; Kumar, P.; Kumar, A.; Sharma, P. Ethanobotanical study of Subhartipuram, Meerut, Uttar Pradesh, India. I. Diversity and pharmacological significance of trees. Int. J. Pharma. Res. 2019, 11, 782-94, https://doi.org/10.31838/ijpr/2019.11.04.078. 